\title{
Role of GLI Transcription Factors in Pathogenesis and Their Potential as New Therapeutic Targets
}

\author{
Maja Sabol, Diana Trnski, Vesna Musani, Petar Ozretić (iD and Sonja Levanat * \\ Laboratory for Hereditary Cancer, Division of Molecular Medicine, Ruđer Bošković Institute, Bijenička cesta 54, \\ 10000 Zagreb, Croatia; maja.sabol@irb.hr (M.S.); diana.trnski@irb.hr (D.T.); vmusani@irb.hr (V.M.); \\ pozretic@irb.hr (P.O.) \\ * Correspondence: levanat@irb.hr; Tel.: +385-1-4571-267; Fax: +385-1-4561-010
}

Received: 23 July 2018; Accepted: 25 August 2018; Published: 29 August 2018

\begin{abstract}
GLI transcription factors have important roles in intracellular signaling cascade, acting as the main mediators of the HH-GLI signaling pathway. This is one of the major developmental pathways, regulated both canonically and non-canonically. Deregulation of the pathway during development leads to a number of developmental malformations, depending on the deregulated pathway component. The HH-GLI pathway is mostly inactive in the adult organism but retains its function in stem cells. Aberrant activation in adult cells leads to carcinogenesis through overactivation of several tightly regulated cellular processes such as proliferation, angiogenesis, EMT. Targeting GLI transcription factors has recently become a major focus of potential therapeutic protocols.
\end{abstract}

Keywords: HH-GLI signaling pathway; GLI transcription factors; signal transduction; malformations; cancer; therapy

\section{Introduction}

The Hedgehog-GLI (HH-GLI) pathway is one of the major developmental pathways. Depending on the inputs, the pathway can be directly or indirectly modulated by proliferative and oncogenic signals. The GLI transcription factors have an important role in the intracellular signaling cascade, acting as main mediators of HH-GLI signaling. Considering the complexity of various aspects of the HH-GLI pathway, including crosstalk with other pathways, levels and limitations of Smoothened (SMO) antagonists, the investigators have moved their attention to downstream targets and components. Today, focus has turned to GLI proteins as more attractive potential targets, taking into account both canonical and non-canonical pathway activation by multiple important signaling pathways.

\section{The HH-GLI Signaling Pathway}

The Hedgehog-GLI (HH-GLI) signaling pathway is a conserved pathway that was first discovered in genetic analyses of segmental development in Drosophila melanogaster during the 1980s [1]. This pathway plays a critical role during embryonic development, and later in the adult organism in the maintenance of stem cells, tissue homeostasis, hematopoiesis and in the immune system [2-8]. The pathway has also been implicated in the development of various cancer types [9].

Even though the pathway is conserved in animals, a unique characteristic of vertebrate HH-GLI signaling is the requirement of primary cilia for proper signal transduction [10]. The primary cilium is a long, non-motile, thin organelle protruding from the apical surface of almost all cell types. It is fundamentally important for normal cell signaling during development and homeostasis. These signaling functions are carried out by various signaling molecules localized to the cilium, such as 
transmembrane receptors that allow for responses to external stimuli and regulatory proteins at the basal body, transition zone and distal regions of the cilium that control the signaling steps [11].

\subsection{Signaling at the Membrane}

In mammals the HH-GLI signaling pathway consists of three HH ligands (Desert, Indian and Sonic Hedgehog, DHH, IHH and $\mathrm{SHH}$ ), two 12-pass transmembrane receptors named Patched1 (PTCH1) and Patched2 (PTCH2), a 7-pass transmembrane G-protein coupled receptor-like protein Smoothened (SMO) and three transcription factors, named GLI1, GLI2 and GLI3, which are regulated by Suppressor of Fused (SUFU). However, PTCH1 is the main receptor, and PTCH2 is rarely described. In the inactive state, PTCH1, a constitutive inhibitor of HH-GLI signaling, is located in the cilium membrane. This inhibition is carried out by repression of the co-receptor SMO. PTCH1 represses ciliary localization of SMO, a necessary step for pathway activation in mammals [12].

Binding of the ligand HH to PTCH1 relieves the repression of SMO and leads to the activation of the transcriptional factors GLI. GLI1 functions as a transcriptional activator, while GLI2 and GLI3 can act as activators or repressors depending on the cellular context [13]. GLI2 and GLI3 are the primary mediators of signal transduction and GLI1 being a target gene acts as a positive feedback to reinforce GLI activity [14] (Figure 1).
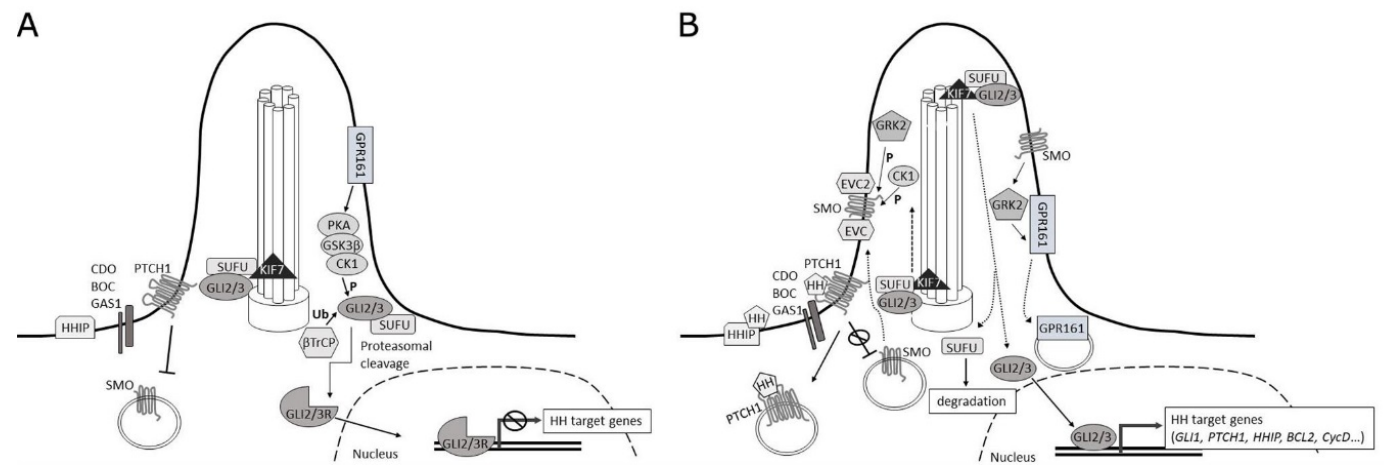

Figure 1. HH-GLI signaling pathway. (A) pathway inactive. (B) pathway active.

For high-affinity $\mathrm{HH}$ binding PTCH1 requires several co-receptors, namely CAM-related/ downregulated by oncogenes (CDO) and brother of $\mathrm{CDO}$ (BOC), as well as growth-arrest specific 1 (GAS1). By binding with PTCH1 these proteins form a multimolecular complex and act collectively as co-receptors for $\mathrm{HH}$ and to promote signal transduction. Deletion of all three co-receptors results in the near complete abrogation of $\mathrm{HH}$ signaling and failure to promote tumorigenesis [15]. The $\mathrm{HH}$ proteins are also regulated by glypicans, which enhance their stability and promote their internalization with PTCH1 [16]. Hedgehog interacting protein (HHIP), another cell surface protein has been identified to regulate $\mathrm{HH}$ binding to PTCH1 [17]. The general hypothesis is that HHIP acts to bind and sequester $\mathrm{HH}$, making it unavailable to PTCH1 for pathway activation. This affects both the $\mathrm{HH}$ secreting cell and the surrounding cells. This makes HHIP a negative regulator of the pathway [18].

In recent years much effort has been put into deciphering of how exactly PTCH1 regulates SMO and how SMO relays the signal to the cytoplasm. Even though there have been numerous discoveries, these questions are still not completely answered. It has been postulated that since PTCH1 harbors homology with the resistance-nodulation-division (RND) family of bacterial membrane transporters, it could serve as a transporter for an endogenous small-molecule SMO modulator [19]. However, a transporter function for PTCH1 has not yet been demonstrated. Cholesterol has been suggested as an endogenous SMO regulator [20-24]. SMO has two separate domains capable of binding steroidal ligands, the extracellular cysteine rich domain (CRD) and the extracellular part of the 7-trans-membrane domain (7TMD), that also binds cyclopamine [25]. It has been found that cholesterol is both necessary 
and sufficient to activate SMO, but it is unclear which domain is crucial for the activating effect of cholesterol [22,25]. Mutational analyses conducted by Luchetti et al. indicate that cholesterol mediates its activating effect on SMO through the CRD binding-site and which then activates the downstream signaling cascade [25]. It is hypothesized that PTCH1 might act to prevent the access of SMO to cholesterol, or in case that cholesterol functions as a constitutive co-factor of SMO activity PTCH1 might regulate another lipidic inhibitor [24]. Recently Huang et al. have been able to describe the structural basis of SMO activation and have observed that SMO activation leads to the opening of a tunnel that runs from the inner leaflet of the membrane through the 7TM site to an extracellular opening near the CRD. The role of this tunnel is yet to be deciphered, but they propose the tunnel serves as a path for cholesterol involved in SMO activation, to ascend from the membrane to the CRD, providing an answer to the question of how cholesterol might be presented to the CRD in vivo [23]. Another interesting domain is the cytoplasmic tail of SMO, or the C-terminal tail (CTT), which also appears to be involved in the endogenous modulation of SMO through phosphatidylinositol 4-phosphate (PI4P) that promotes its phosphorylation and activation [26].

It has been shown that upon pathway activation, the SMO CTT becomes phosphorylated by casein kinase $1, \alpha(\mathrm{CK} 1 \alpha)$ and the GPCR kinase 2 (GRK2). These phosphorylation events trigger SMO ciliary localization and induce a conformational switch leading to dimerization of the activated SMO CTT $[27,28]$.

\subsection{Cytoplasmic Signaling Cascade}

There has been much debate on the mechanism of further signal transduction toward GLI activation. GPR161, a G-protein coupled receptor, has recently come into focus and has been proposed to function downstream of SMO to repress basal HH signaling by promoting production of GLI3 repressor form (GLI3R) [29]. Upon HH stimulation, GRK2 would initiate ciliary clearance of GPR161 and promote downstream signal transduction [30].

A study by Pusapati et al. has established that GRK2/3 is required for $\mathrm{HH}$ signaling at a step downstream of SMO, but they suggest a GPR161 dependent function in relation to GLI3R-regulated genes, but a GPR161-independent function for regulating high-level HH responses by GLI2 activator form (GLI2A) [31].

A role for EVC and EVC2 proteins in the transduction of the HH signal from SMO to PKA and SUFU has also been suggested. It was proposed that upon $\mathrm{HH}$ induced phosphorylation and ciliary accumulation, SMO interacts with EVC/EVC2, which then leads to the inhibition of GLI3R formation and induction of GLI activator formation [32,33].

SUFU is a major negative regulator of HH-GLI signaling activity that directly binds the GLI proteins in the absence of $\mathrm{HH}$ stimulation and thereby prevents their translocation to the nucleus and subsequent pathway activation [34]. By tethering the GLI proteins in the cytoplasm, SUFU promotes their degradation or processing into repressor forms [35].

When the pathway is inactive, the binding of SUFU to GLI2 and GLI3 sequesters them in a cytoplasmic complex containing KIF7, a cilium associated kinesin. This prevents full length GLI to enter the nucleus and activate target gene transcription. Also, by masking the GLI NLS (nuclear localization signal) SUFU prevents nuclear accumulation of GLI2 and GLI3 mediated by Kap $\beta 2$ [36,37].

Moreover, binding of SUFU to GLI2/3 potentiates the formation of GLI2/3 repressor forms (GLI2R and GLI3R), after sequential phosphorylation of full length GLI by protein kinase A (PKA), glycogen synthase kinase 3 beta (GSK3B) and casein kinase 1 (CK1) within the complex. After phosphorylation, full length GLI2 and GLI3 are cleaved through the ubiquitin-proteasome pathway mediated by the ubiquitin E3 ligase SCF $\beta \operatorname{TrCP}$, resulting in the formation of $\mathrm{N}$-terminal repressor forms $[38,39]$. These truncated GLI proteins inhibit target gene transcription by competing with GLI2/3 full length forms or recruit co-repressors $[40,41]$.

Upon signaling activation, the complex comprising of SUFU and GLI2/3 is translocated to the tip of the primary cilium, where its dissociation is initiated. Full length GLI2 and GLI3 are free to 
translocate to the nucleus as transcriptional activators, while SUFU is degraded. A key function of SUFU is also preserving a pool of full length GLI2/3 proteins by preventing complete degradation mediated by SPOP, and as soon as HH-GLI signaling is activated these proteins are derepressed and readily activate target gene transcription [42,43]. In addition to the cytoplasm, SUFU also regulates GLI proteins in the nucleus, where it is able to recruit specific co-repressor complexes, such as SAP18-mSin3-HDAC and p66 $\beta$ and thereby suppress GLI transcription activity [44-46].

\subsection{Nuclear Signaling}

GLI proteins are members of the Kruppel family of transcription factors. They have five conserved zinc-finger DNA binding domains and bind to the consensus sequence GACCACCCA in the promoter of their target genes [47]. GLI proteins can recognize variant binding sites with lower affinity that can still lead to strong transactivation [48]. The outcome of HH-GLI signaling depends on the receiving cell type, and regulates various cellular responses such as proliferation and differentiation (Cyclin D1/2, Cyclin E, E2F1, N-MYC, FOXM1, PDGFR $\alpha$ ), cell survival (BCL2), self-renewal (SOX2, NANOG, BMI1), angiogenesis (VEGF, CYR61, ANG1/2), epithelial-mesenchymal transition (EMT) (SNAIL1, ZEB1, ZEB2, TWIST2, MMP9), invasiveness (Osteopontin) and HH-GLI pathway autoregulation (GLI1, PTCH1, HHIP1). Targeting GLI1 leads to amplification of the signal upon pathway activation, while PTCH1 and HHIP1, both negative regulators of the pathway, represent negative feedback loops controlling the extent of $\mathrm{HH}$ signaling $[49,50]$.

\subsection{The GLI Code}

The GLI proteins possess both activator and repressor capabilities. GLI2 and GLI3 harbor a repressor domain at their amino terminus and an activator domain at their carboxy terminus. GLI1 on the other hand, lacks the amino-terminal repressor domain and acts as a pathway activator. The combinatorial and cooperative function of the three GLI transcription factors is known as the GLI code [51-53]. In the absence of HH signals, the GLI code is driven toward a repressive output (GLIR) leading to pathway downregulation. In this scenario, GLI2/3 are processed into transcriptional repressors and GLI1 is not transcribed. Canonical activation of the pathway through HH blocks GLI processing and promotes target gene activation through active GLI forms (GLIA). Even though at first the regulation of the GLI code seemed to be entirely dependent on the canonical HH-GLI signaling, it has become evident that non-HH signals can also contribute to the regulation of the GLI code, leading to non-canonical HH pathway activation [53]. These new findings contribute to the understanding of how the GLI code is disrupted in human cancer.

\section{GLI Genes and Protein Isoforms}

GLI1 gene is located at 12q13.3-14.1, the gene is comprised of 12 coding exons and contains 3318 base pairs giving rise to a full length 1106-amino acid protein [54]. GLI2 gene is located at 2q14, consists of 13 coding exons and contains $4758 \mathrm{bp}$ giving rise to the full length 1586-aa protein $[55,56]$. GLI3 gene is located at $7 \mathrm{p} 13$, consists of 14 coding exons and contains $4740 \mathrm{bp}$ giving rise to the full length 1580-aa protein [57,58].

Recent evidence indicates that both GLI1 and GLI2 can undergo alternative splicing, that leads to the synthesis of their truncated variants (Figure 2). GLI1 has currently five known isoforms. Of those five, two are splice variants of the full-length mRNA, and at least one isoform is generated by a posttranslational N-terminal truncation of the full-length protein [59]. The GLI1 $\Delta \mathrm{N}$ splice variant lacks 128 amino acids at the $\mathrm{N}$-terminus due to skipping exons 2 and 3. Even though the GLI1 $\Delta \mathrm{N}$ variant lacks the N-terminal SUFU binding domain, it was shown to be a less potent transcriptional activator than the full-length protein with a weakened ability to translocate to the nucleus. Also, even though GLI1 $\triangle \mathrm{N}$ and GLI1FL have the same DNA binding domain, it seems that there are differences in their target gene activation mechanism [60]. 
GLI1

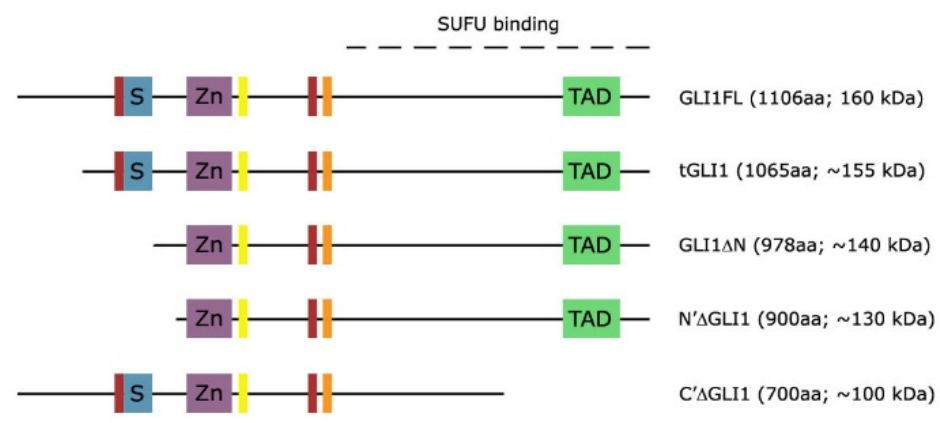

\section{GLI2}

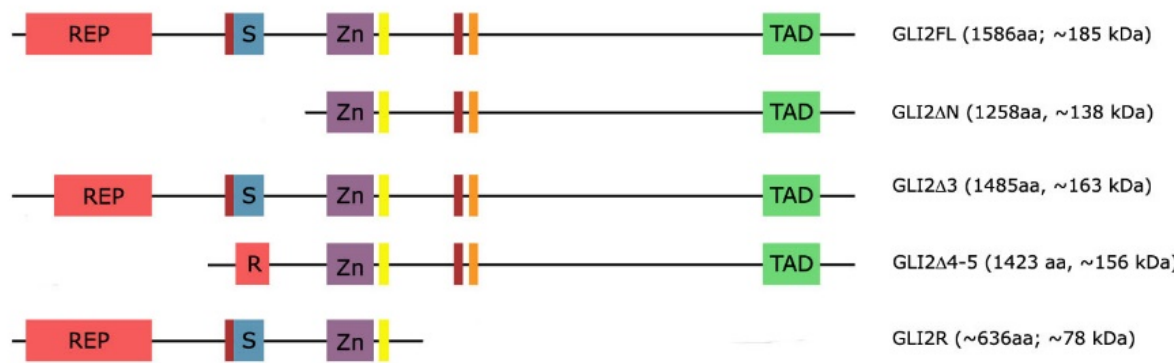

\section{GLI3}

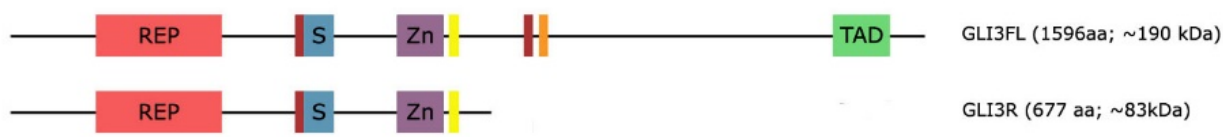

\begin{tabular}{lll} 
Repressor domain & Nuclear localization \\
\hline N' and $C^{\prime}$ degrons & Nuclear export \\
\hline SUFU binding site & Transactivation domain \\
\hline Zinc-finger motif &
\end{tabular}

Figure 2. Schematic representation of GLI isoforms.

Another splice variant of GLI1 was identified in malignant glioma. This variant, named tGLI1, lacks the entire exon 3 and part of exon 4 of the full-length GLI1 gene [61]. This variant has all functional domains present in GLI1 preserved and thus retains the ability to translocate to the nucleus, activate target genes and respond to SHH stimulation. The expression of tGLI1 was detected only in cell lines and primary specimens derived from human glioblastoma and breast cancer, but not normal brain and breast tissue. This is a distinct feature compared to GLI1 and GLI1 $\triangle \mathrm{N}$ as both those proteins are present in normal and cancer cells. In addition, tGLI1 also has multiple direct transcriptional targets that differ from those of GLI1, such as CD24, VEGFA, MMP2 and MMP9, that can contribute to an aggressive cell phenotype [54,62].

The precise function of tGLI1 compared to GLI1 will need to be investigated in detail. The difference between tGLI1 and GLI1 is 41 amino acids, which is approximately $4.5 \mathrm{kDa}$. Because of this 
minimal difference in size, and the fact that most commercial antibodies detect both isoforms, it is possible that in the past some functions correlated with GLI1 have actually been due to tGLI1 [54].

Two isoforms $\mathrm{N}^{\prime} \Delta$ GLI1 and the $\mathrm{C}^{\prime} \Delta$ GLI1 have been identified as weak activators and repressors, respectively [63]. $\mathrm{N}^{\prime} \Delta$ GLI1 lacks the $\mathrm{N}$-terminus of full length GLI1 and since it is produced from the full-length cDNA it is different from the splice variant GLI1 $\Delta \mathrm{N}$. As opposed to the splice variant, which is exceedingly rare, the $\mathrm{N}^{\prime} \Delta$ GLI1 isoform is 10-fold more abundant than the full-length protein, due to loss of a degron $\mathrm{N}$ and a key binding site for SUFU. p53 might be involved in $\mathrm{N}^{\prime} \Delta$ GLI1 phosphorylation and subsequent inactivation. $C^{\prime} \Delta$ GLI1 on the other hand, might act as a negative feedback as it resembles the GLI3 repressor form, but unlike GLI3R, it is not inhibited by HH signaling [64].

GLI2, like GLI1, possesses splice variants. The N-terminally truncated GLI2 $\Delta \mathrm{N}$ splice variant was at first thought to represent the entire GLI2 protein, but Roessler et al. showed that the full-length GLI2 contains an additional 328 amino acids at the amino terminus, containing the repressor domain. The full length GLI2 was shown to be up to 30-fold less potent than the GLI2 $\Delta$ N variant [65].

Later on, two more splice variants of GLI2 were discovered, namely GLI2 $\Delta 3$, a variant arising from skipping exon 3, and GLI2 $\Delta 4-5$, a variant lacking exon 4 and 5 , supporting the hypothesis that alternative splicing may be another important regulatory mechanism for the modulation of repressor and activator properties of GLI2 protein in addition to proteolytic processing [55]. For GLI3, on the other hand, no splice variants have been found and verified to date.

\section{Role of GLI in Development}

HH-GLI signaling plays a key role during development of both vertebrates and invertebrates, especially during patterning and morphogenesis. The $\mathrm{HH}$ proteins are morphogens that induce distinct cell fates in a dose-dependent manner. They can also regulate cell proliferation and control the form of a developing organ. HH-GLI signaling is involved in development of almost every organ during the development of vertebrate embryo (e.g., bone and cartilage, limbs, neurons, cerebellum, eye, gut, gonads, heart, lung, pancreas, muscle, lateral symmetry, angiogenesis) [66]. Therefore, it is not surprising that the defects in HH-GLI signaling lead to development of many different congenital malformations and syndromes.

$\mathrm{SHH}$ is expressed in numerous tissues with polarizing activities during development. $\mathrm{SHH}$ expression can first be detected in the node, then in the notochord, floor plate of the neural tube, and in the zone of polarizing activity (ZPA) in the limb buds. Teeth, skin and several other tissues with inductive interactions also express SHH during development. The expression of HH-GLI target genes, PTCH1 and GLI1, are mostly restricted to proliferating cells adjacent to SHH-expressing tissues, while GLI2 and GLI3 show broader expression in proliferating cells in regions more distant to SHH [67].

Expression of Gli genes in different embryonic tissues seem to follow similar rules. For example: during the mouse limb development, at 9.5 days postcoitum (dpc) Gli2 and Gli3 are expressed in the entire anterior-posterior $(\mathrm{A} / \mathrm{P})$ axis of the newly formed limb bud while Gli1 is confined to the posterior half. At $10.5 \mathrm{dpc}$ Gli2 and Gli3 remain confined to the anterior limb bud while their expression is excluded from the posterior part, while Gli1 fades from the most posterior domain. At $11.5 \mathrm{dpc}$ the posterior area which corresponds to the ZPA is devoid of any Gli expression and is surrounded by a Gli1-positive, but Gli3-negative domain. The anterior part of the limb bud expresses Gli2 and Gli3. At $12.5 \mathrm{dpc}$ Gli1 transcripts are found in the condensing mesenchyme while the surrounding mesenchyme expresses Gli2 and Gli3 [68].

Mouse Gli mutants were generated to discriminate between overlapping and unique requirements for the three genes. Gli1 ${ }^{-1}$ mutant seem to be normal, fertile and can live past 1 year of age and show no obvious behavioral abnormalities [69]. Mouse Gli1 $^{-/-}$mutants show changes in T cell development in the thymus [70]. Gli2 mutants have numerous skeletal defects and abnormal lungs. They also lack a floorplate and adjacent ventral intermediate region (VIR) cells in the spinal cord [69]. Mouse Gli2-/show changes in T cell development [71]. Gli2 ${ }^{-1-}$ mouse embryos exhibit severe defects in hindbrain ventral patterning, and it is thought that GLI2 activator function is required for the development of 
specific progenitor cells that will become motoneurons and interneurons in the ventral neural tube [72]. Gli2 mutant mice embryos also show abnormal pituitary development, with normally patterned but smaller pituitary, and have decreased number of anterior pituitary secreting hormone cells: specifically, corticotropes, somatotropes and lactotropes [73]. Gli3 ${ }^{-1-}$ mutant mice die around birth, exhibiting severe craniofacial abnormalities, often combined with extracephaly and an enhanced polydactyly with up to nine digits. Mouse Gli3 mutants show changes in T cell development in the thymus and B cell development in the fetal liver [74-76]. Heterozygous mutants show preaxial polydactyly [77].

\section{Role of GLI in Congenital Malformations and Syndromes}

Mutations in GLI genes are found in diverse developmental malformations, both syndromic and not. Polydactyly is the only congenital malformation that results from mutations of all three GLI genes. Syndactyly and polydactyly — respectively characterized by fused and supernumerary digits—are among the most common congenital limb malformations, with syndactyly presenting at an estimated incidence of 1 in 2000-3000 live births and polydactyly at a frequency of 1 in approximately 700-1000 live births [78]. Polydactyly can most easily be classified as preaxial in which the extra digit is located outside the thumb or great toe; postaxial in which the extra digit is located outside the fifth digit, and central (mesoaxial) polydactyly in which the extra digit is located among three central digits [79].

\subsection{GLI1}

Until recently no GLI1 mutations have been described in any developmental syndrome. In 2017 Palencia-Campos et al. described three independent families with GLI1 mutations with apparent recessive mode of inheritance. The phenotype of affected individuals closely resembled Ellis-van Creveld syndrome usually caused by mutations in EVC1 or EVC2 genes, normally located in primary cilia. The phenotype includes short stature, bilateral postaxial hexadactyly of hands and feet in two families and postaxial polydactyly type A of feet in the third family with normal stature. Additional features included shortening of distal lower extremities, mild nail dysplasia, atrial septal defect, genu valgum, and high palate. The GLI1 mutations were found in homozygous form in all more severely affected individuals, but some individuals with polydactyly had the mutation in heterozygous form. Two of the mutations are located at the C-terminus of GLI1 gene, c.1930C > T and c.2340G > A and are coding for the truncated forms of the GLI1 protein lead to the phenotype with short stature, while the third (c.337C > T) located in the $\mathrm{N}$-terminal part is believed to be subjected to nonsense medicated decay [80].

\subsection{GLI2}

Holoprosencephaly (HPE) is a developmental defect of the forebrain characterized by the incomplete separation of the cerebral hemispheres into distinct halves, followed by facial anomalies in most cases. Clinically, the range of symptoms is very wide, from minor facial signs to complex craniofacial anomalies [81]. Mutations have been found in several genes: SHH, GLI2, PTCH1, TGIF1, ZIC2 and SIX3, but also in GAS1, EYA4, DISP1, TDGF1, FOXA2, LRP2, LSS, HHIP, SMO, BMP4, CDON, CDC42, ACVR2A, OTX2, and WIF1 [82].

GLI2 mutations have been reported in patients with HPE and/or HPE-like (HPE-L) phenotypes, and usually associated with pituitary anomalies and postaxial polydactyly $[73,83,84]$. However, other wide phenotypic variety of other craniofacial anomalies have also been reported $[82,85]$.

Truncating mutations of GLI2 are usually associated with pituitary anomalies, polydactyly and subtle facial features, not typical HPE [73]. The location of the mutations did not correlate with the clinical findings. Missense mutations are often found in patients with craniofacial defects [82,85].

Several large deletions of GLI2 have been described in individuals with polydactyly and/or pituitary anomalies. Gustavsson et al. reported a patient with a 2;20 translocation and $20 \mathrm{Mb}$ deletion on chromosome 2q14.2-q22.1, including 43 genes, one of which was GLI2. Detected symptoms included hypospadias, postaxial polydactyly, double-left-sided ureters, undescended testes, exotropia 
and amblyopia of the left eye, growth hormone deficiency, as well as Lupus anticoagulantia [86]. Kevelam et al. reported a $1.3 \mathrm{Mb}$ submicroscopic heterozygous deletion in 2q14.2, which includes GLI2 and four other genes. The patient had normal psychomotor development, but presented bilateral cleft lip and palate and abnormal pituitary gland formation [87]. Greally et al. reported a patient with an $18.9 \mathrm{Mb}$ deletion containing 54 OMIM genes, including GLI2. At birth the patient had congenital right talipes equiovarus, a skin tag on the left fifth finger, a wide anterior fontanelle and dysmorphic ears. Subsequent physical examinations showed changes in the shape of forehead, nose, teeth, eyes and eyebrows, changes on the palms and hands, and mild penile phimosis [88]. Ma et al. reported a patient with $10.79 \mathrm{Mb}$ deletion at 2q13q14.2 which contains 38 OMIM genes. The patient showed hypothyroidism associated with a normal size and position of the thyroid gland, as well as negative thyroid antibodies, global development delay and Mullerian agenesis [89]. Kordaß et al. reported a family with $4.3 \mathrm{Mb}$ deletion at 2q14. At birth the patient had short stature, low weight, microcephaly, ventricular septal defect (VSD) and atrial septal defect type II (ASDII). At age 6 she underwent endocrine evaluation and IGF1 and IGFBP3 showed reduced levels. At age 25 she was $150 \mathrm{~cm}$ tall and showed scoliosis, mild facial dysmorphism and abnormal temporal myelinization but psychomotoric development was apparently normal. The mutation was shared with her paternal grandmother who also had small stature [90]. Goumy et al. reported a family with $5.8 \mathrm{Mb}$ deletion at $2 \mathrm{q} 14.1 \mathrm{q} 14.3$ encoding 24 genes. The mutation was discovered during prenatal diagnosis due to intrauterine growth retardation and partial agenesis of corpus callosum. The patient was born with severe growth retardation. At 6 months, he demonstrated a wide range of relatively mild altered facial features. At 9 months, he showed mild developmental delay. His mother and one brother had the same mutation. The mother had learning difficulties at school, but no other phenotypic abnormalities. The brother had similar facial features as the proband as well as psychomotor retardation [91]. Niida et al. reported a patient with $6.6 \mathrm{MB}$ deletion at 2q14.1q14.3 encoding 28 OMIM genes. The patient had cleft palate and flat nasal bridge, but no polydactyly or other facial or exterior dysmorphic features. She had learning difficulties in school, social communication problems and was diagnosed with selective mutism. She had short stature and delayed puberty [92].

\subsection{GLI3}

Greig cephalopolysyndactyly syndrome (GCPS) is a congenital pleiotropic syndrome associated with multiple anomalies. It is rare, with estimated range of $1-9 / 1,000,000$. It is caused by the loss of function of GLI3 gene and is inherited in an autosomal dominant pattern [93]. Individuals with large deletions encompassing GLI3 show more severe phenotype [57,92]. Mutations in the $5^{\prime}$ region close to the or within the zinc finger domain cause the majority of GCPS [94], other mutations have been detected, such as missense, splicing or truncating mutations elsewhere in the gene. They lead to haploinsufficiency, loss of the DNA-binding capacity, or activation of nonsense-mediated mRNA decay, or formation of unstable or mislocalized proteins [57] (Table 1). 
Table 1. GLI3-associated syndromes and their features.

\begin{tabular}{|c|c|c|c|c|c|c|c|}
\hline Syndrome/Condition & $\begin{array}{l}\text { MIM } \\
\text { ID\# }\end{array}$ & Hand Defects & Feet Defects & $\begin{array}{c}\text { Cranial } \\
\text { Malformations }\end{array}$ & $\begin{array}{c}\text { Intellectual } \\
\text { Disability }\end{array}$ & Other & Reference \\
\hline $\begin{array}{c}\text { Greig } \\
\text { cephalopolysyndactyly } \\
\text { syndrome }\end{array}$ & 175700 & $\begin{array}{l}\text { postaxial } \\
\text { polydactyly, } \\
\text { cutaneous } \\
\text { syndactyly }\end{array}$ & $\begin{array}{c}\text { preaxial } \\
\text { polydactyly, } \\
\text { cutaneous } \\
\text { syndactyly }\end{array}$ & $\begin{array}{l}\text { hypertelorism, } \\
\text { macrocephaly } \\
\text { with frontal } \\
\text { bossing }\end{array}$ & sometimes & $\begin{array}{c}\text { central nervous } \\
\text { system (CNS) } \\
\text { anomalies, hernias }\end{array}$ & [93] \\
\hline $\begin{array}{c}\text { Greig } \\
\text { cephalopolysyndactyly } \\
\text { contiguous gene deletion } \\
\text { syndrome }\end{array}$ & 175700 & $\begin{array}{l}\text { postaxial } \\
\text { polydactyly, } \\
\text { cutaneous } \\
\text { syndactyly }\end{array}$ & $\begin{array}{c}\text { preaxial } \\
\text { polydactyly, } \\
\text { cutaneous } \\
\text { syndactyly }\end{array}$ & $\begin{array}{l}\text { hypertelorism, } \\
\text { macrocephaly, } \\
\text { hydrocephalus }\end{array}$ & often & $\begin{array}{l}\text { seizures, } \\
\text { ophthalmologic } \\
\text { findings }\end{array}$ & {$[57,92]$} \\
\hline Acrocallosal Syndrome & 200990 & $\begin{array}{l}\text { preaxial and } \\
\text { postaxial } \\
\text { polydactyly, } \\
\text { cutaneous } \\
\text { syndactyly }\end{array}$ & $\begin{array}{c}\text { preaxial } \\
\text { polydactyly }\end{array}$ & $\begin{array}{l}\text { macrocephaly, } \\
\text { widely spaced } \\
\text { eyes, absence of } \\
\text { the corpus } \\
\text { callosum, } \\
\text { hydrocephalus }\end{array}$ & yes & $\begin{array}{c}\text { seizures, } \\
\text { interhemispheric cysts, } \\
\text { umbilical hernia }\end{array}$ & {$[95,96]$} \\
\hline Pallister-Hall syndrome & 146510 & $\begin{array}{l}\text { central } \\
\text { polydactyly, } \\
\text { postaxial } \\
\text { polydactyly }\end{array}$ & none & bifid epiglottis & no & $\begin{array}{l}\text { hypothalamic } \\
\text { hamartoma, } \\
\text { imperforate anus, } \\
\text { renal abnormalities, } \\
\text { genital defects }\end{array}$ & {$[57,97]$} \\
\hline
\end{tabular}


Acrocallosal syndrome (ACS, ACLS) was first described in 1979 and has a lot of the same features of GCPS, but usually with a more severe phenotype. It is very rare and only about 50 cases have been reported. The disorder is genetically heterogeneous and in most cases the etiology is unknown, although autosomal recessive mutations in KIF7 gene and heterozygous missense mutations in GLI3 have been reported [95].

Pallister-Hall syndrome (PHS) displays a wide range of severity, from very mild cases with subtle insertional polydactyly to lethal cases [57]. It is inherited in an autosomal dominant pattern and shows a complete penetrance. It is a rare syndrome and the prevalence is unknown [97]. It is caused mainly by truncating mutations in the middle third of the GLI3 gene, resulting in a constitutive repressor protein [57].

\section{Activation of GLI in Tumorigenesis}

Modes of HH-GLI signaling activation are different among different cancer types. Some tumor types depend on mutations of specific pathway components such as PTCH1, SMO and SUFU. This is mostly the case in basal cell carcinoma and medulloblastoma [98,99]. Another example are tumors that depend on specific gene amplification, more precisely on GLI1 gene amplification, such as glioblastoma or rhabdomyosarcoma [54,100].

HH-GLI signaling pathway or more precisely, GLI proteins activate the transcription of many target genes which are involved in various aspects of tumorigenesis [49]. For example, cell proliferation is enhanced by expression of D-type cyclins [101]; production of B-cell lymphoma 2 (BCL2), an anti-apoptotic protein, mediates cell survival [102]; angiogenesis is activated by upregulation of angiopoietins and vascular endothelial growth factor (VEGF) [103]; transcription of SNAG family of transcriptional repressors initiates the epithelial-to-mesenchymal transition in metastasis [104], while GLI-mediated regulation of SOX2 and NANOG expression facilitates self-renewal of stem cells $[105,106]$. In consequence, it is expected that dysregulation of HH-GLI signaling could lead to wide variety of malignancies [107].

Aberrant HH-GLI pathway activation, usually manifested by upregulation of GLI1 and PTCH1 expression, has been found in a multitude of human cancer types, including basal cell carcinoma (BCC), medulloblastoma (MB), glioma, melanoma, gastrointestinal, colon, breast, lung, liver, prostate and pancreatic cancer [108]. This aberrant activation can be ligand dependent, ligand independent or caused by genetic and epigenetics mechanisms. The latter include inactivating loss-of-function mutations and promoter hypermethylation/transcriptional inactivation of negative regulators of the pathway (e.g., PTCH1, SUFU) or activating, gain-of-function mutations and promoter hypomethylation/transcriptional activation of positive regulators of the pathway (e.g., SHH, SMO) [109].

\subsection{Ligand Dependent Signal Transduction}

Ligand-dependent activation of the pathway can be autocrine, paracrine or reverse paracrine. In the autocrine model tumor cells secrete and respond to $\mathrm{HH}$ ligands and show increased ligand expression in the absence of genetic mutations of HH-GLI components. This type of signaling has been identified in lung, pancreatic, gastrointestinal, colon and prostate cancer as well as glioma and melanoma [110-119]. In the paracrine activation of HH-GLI signaling, tumor cells produce the ligand $\mathrm{HH}$, which then activates HH-GLI signaling in the surrounding stromal cells. Activation of the pathway in these cells leads to production of factors that sustain tumor cell growth. This type of signaling has been identified in experimental models for prostate, pancreatic and colon cancer [120,121]. In the reverse paracrine model, the ligand is produced by stromal cells, which activates the signaling pathway in tumor cells. This type of signaling activation has been described in B-cell lymphoma, multiple myeloma and leukemia [107]. The HH-GLI signaling pathway has also been implicated cancer stem cell (CSC) self-renewal, contributing to increasing tumor initiating cell populations, growth and 
tumorigenicity. Activation of HH-GLI signaling has been detected in CSCs of glioma, pancreatic cancer, breast cancer, melanoma, colon cancer, as well as some hematological malignancies [107,122,123].

\subsection{Ligand Independent Non-Canonical Activation and Cross-Talk with other Pathways}

In addition to ligand-dependent, canonical pathway activation, non-canonical activation of the pathway through cross-talk with other oncogenic pathways has been detected in many cancer types. This type of signaling bypasses the ligand-receptor signaling axis and directly relies on activation of the GLI transcription factors through interactions with members of other signaling pathways. It is mainly investigated in the context of malignant diseases in order to understand the underlying mechanisms of GLI activation that could shed light on potential therapeutic strategies.

To date there are multiple lines of evidence that support the cross talk between the HH-GLI signaling pathway and the RAS-RAF-MEK-ERK, PI3K/AKT and TGFB/SMAD signaling pathways. How exactly the RAS-RAF-MEK-ERK cascade causes activation of GLI1 transcription is not completely understood. A study by Whisenant et al. proposes that this signaling axis regulates GLI1 and GLI3 through their phosphorylation by ERK and JNK MAP kinases [124]. It has been shown that oncogenic KRAS can block GLI1 degradation and lead to activation of HH-GLI signaling in pancreatic cancer cells [125]. Also, oncogenic NRAS and HRAS increase GLI1 function in melanoma cells, and HH-GLI signaling is required for NRAS-induced mouse melanoma growth [118]. Riobo et al. have shown that activation of the PI3K/AKT signaling pathway increases SHH-induced transcriptional activity of GLI through antagonizing PKA-dependent GLI2 inactivation, proposing a synergistic role for PI3K/AKT and HH-GLI signaling pathways. Therefore, loss of PTEN, a negative regulator of PI3K, or overexpression of IGF1, which are frequent events in tumors, could upregulate PI3K/AKT activity to stimulate even low levels of HH-GLI signaling [126]. TGFB signaling has been shown to regulate HH-GLI activity independently of SMO by directly promoting GLI2 transcription through SMAD3/ $\beta$-catenin cooperation [127]. TGFB and RAS signaling regulates the expression of GLI1 and its target genes in pancreatic ductal adenocarcinoma [128]. An interaction between EGFR signaling and the HH-GLI pathway has also been reported. Oncogenic transformation of the cells can be also induced by synergistic activation of the HH-GLI and epidermal growth factor receptor (EGFR) pathways. This activation depends on EGFR-mediated activation of the MEK/ERK signaling which induces transcription factor AP-1 (JUN) that cooperates with GLI1 and GLI2 [129]. Members of the Protein kinase C (PKC) family are also known to modulate HH-GLI signaling. PKC $\alpha$ increases GLI1 transcription in a MEK/ERK dependent manner, while aPKC $\iota / \lambda$ upregulates $\mathrm{HH}$ signaling by directly phosphorylating and activating GLI1. Since aPKC $\iota / \lambda$ is also HH target gene, this positive feedback loop causes sustained $\mathrm{HH}$ activation. PKC $\delta$, on the other hand prevents GLI1 nuclear localization and transcriptional activity, leading to silencing of HH signaling $[130,131]$. The TNF $\alpha / \mathrm{mTOR}$ signaling pathway can activate HH signaling through phosphorylation of GLI1 protein at Ser84 by S6K1, which leads to its release from SUFU in esophageal, pancreatic and gastrointestinal cancer cells [132]. Pro-inflammatory cytokines like TNF and IL1B can cause GLI1 overexpression by direct binding of NFKB1 transcriptional complex to GLI1 promoter, what leads to accumulation of GLI1 in the nucleus. This was observed in pancreatic carcinoma [133], while decreased GLI1 expression caused by inhibition of NFKB was observed in breast cancer [134]. The WIP phosphatase has been shown to increase GLI1 function in melanoma by promoting GLI1 nuclear localization, protein stability and transcriptional activity [135]. P53 has also been shown to interact with GLI1 in a negative reciprocal manner. P53 inhibits the activity, nuclear localization and protein levels of GLI1, while GLI1 conversely inhibits p53 through activation of MDM2 [50,64,136,137]. GLI1 is a direct transcriptional target of EWSR1-FLI1 oncoprotein which is a fusion transcript found in Ewing sarcoma family of tumors and consists of EWSR1 (RNA binding protein 1) and FLI1 (Fli-1 proto-oncogene, ETS transcription factor) genes [138]. MYC proto-oncogene directly regulates transcription of GLI1 which has an anti-apoptotic role in Burkitt lymphoma [139]. Atonal bHLH transcription factor 1 (ATOH1) directly regulates transcription of GLI2 in granule neuron precursors, the cell of origin of medulloblastoma, 
where it plays a critical role in tumorigenesis [140]. Another developmental pathway aberrantly active in some cancers, the Wnt/ $\beta$-catenin pathway, shares reciprocal interactions with HH-GLI signaling on level of GLI1 inducing expression of SNAIL or sFRP1 [141]. A recent study by our lab proposed non-canonical activation of GLI3 in colon cancer cells through a novel mechanism involving deregulated of GSK3B [142].

\subsection{Genetic Changes}

For long time GLI1 gene has been considered as a unique member of the HH-GLI pathway because at that time no somatic mutations have been reported in tumors and it was thought that oncogenic potential of GLI1 could be manifested primarily through either gene amplification or an alternative splicing when novel truncated GLI1 splice variant, tGLI1, with a gain-of-function characteristics was discovered in glioblastoma multiforme and breast cancer [54,61].

Additional post-transcriptional mechanism of GLI1 regulation has been observed on the level of mRNA where nucleotide 2179 is converted to inosine by adenosine deamination (so called A-to-I RNA editing). This leads to a change from arginine to glycine at amino acid position 701 in SUFU binding domain and thus changed GLI1 protein has reduced responsiveness to both negative HH-GLI signaling regulator SUFU and positive regulator DYRK1A kinase. RNA editing of GLI1 has been detected in fetal and adult brain, lung, colon, pancreas and ovary tissues, while, on the contrary, in corresponding tumor cell lines the extent of editing was significantly decreased [143]. GLI1 transcript editing rates were observed higher in relapsed multiple myeloma and plasma cell leukemia, leading to increased GLI1 activity and consequently to malignant regeneration in multiple myeloma [144].

\subsubsection{Gene Amplification}

GLI1 gene has been originally isolated from human glioma cells where it was found being amplified more than 50-fold [145]. Therefore, a connection of GLI proteins with tumorigenesis could have been observed from the beginnings of HH-GLI pathway research in humans. Amplification of GLI1 and GLI2 loci has been detected in medulloblastoma, the most common malignant brain tumor in children [146]. Gain of chromosomal region 12q13.2-q13.3 which surrounds GLI1 genomic locus has been linked to breast cancer development $[147,148]$. In addition, amplification of GLI1 has been also observed in rhabdomyosarcoma [149] and GLI2 in oral squamous cell carcinoma [150].

\subsubsection{Gene Translocation (Fusion)}

In several cases of histologically distinctive soft tissue tumors with pericytic phenotype a new mechanism of GLI1 activation through fusion with actin beta gene (ACTB) has been discovered, and this type of tumor has been defined as 'pericytoma with $t(7 ; 12)^{\prime}$ [151]. An identical fusion transcript including the $5^{\prime}$-part of $A C T B$ and the $3^{\prime}$-part of GLI1 has been also observed in one case of primary bone cancer [152].

\subsubsection{Short Genetic Variations}

Targeted sequencing of GLI genes in cancers has been conducted in several studies. Genetic analysis of GLI1 in Merkel cell carcinoma, an aggressive neuroendocrine skin cancer, has discovered a frequent synonymous substitution c.576G > A found in exon 5 [153]. HH-GLI pathway mutation analysis in T-cell acute lymphoblastic leukemia discovered the presence of two rare somatic missense substitutions-GLI1:c.C1613T (p.S538F) and GLI3:c.G2179A (p.G727R). Both of them are located downstream of the zinc finger domain and considered harmful for the protein by in silico prediction. One additional missense substitution predicted to be damaging has been found GLI3:c.G1097T (p.R366L) but due to the lack of germline DNA it was not possible to determine whether this sequence variation is acquired or inherited [154]. Genetic analysis of frameshift mutation c.821delG in exon 8 of GLI1 in gastric and colorectal cancers has shown that this mutation is more prevalent in CRC than GC and that all mutations have been found in cancers with high microsatellite instability [155]. 
With an increased application of massive parallel sequencing of whole cancer genomes, more mutations in GLI1 and GLI3 have been discovered in breast, colorectal, pancreatic cancers and soft-tissue sarcomas [156-159]. The quick overview of the Catalogue of Somatic Mutations in Cancer (COSMIC) database shows that there are about 100, 30 and 60 sequence variants that could a priori be considered as pathogenic (nonsense substitutions and frameshift indels) found in GLI1, GLI2 and GLI3, respectively [160]. These short genetic variations have been found by sequencing genomes of wide variety cancer types such as breast, skin, kidney, lung, pancreatic, prostate, intestine cancer, etc. As expected, there are many more discovered missense and synonymous substitutions whose potential functional and clinical impact remains to be verified. One study which has shown how missense substitutions could have impact on tumorigenic potential of GLI1 protein has been conducted by Huntzicker et al. [161]. They demonstrated that degradation of GLI1 is regulated by two independent destruction signals called degron $\mathrm{D}_{\mathrm{C}}$ and degron $\mathrm{D}_{\mathrm{N}}$, and that amino acid changes in one or both degrons stabilize GLI1 protein and rapidly accelerates tumor formation in transgenic animals [161].

\subsection{Epigenetic Changes}

Epigenetic changes are heritable phenotype changes without alterations in the DNA sequence. These changes are caused by processes which involve DNA methylation in promoter region of the genes [162-164], remodeling of nucleosome by histone modifications [165] and regulation of gene expression by non-coding RNA molecules such as mircoRNAs (miRNAs) and long non-coding RNAs (long ncRNAs) [166]. Dysregulation of all of these processes has been associated with the development of cancer [167].

\subsubsection{DNA/Protein/Histone Methylation}

GLI3 overexpression caused by promoter hypomethylation has been observed in gastric cancer [168] but its promoter seems not to be affected by hypermethylation in MB [169]. In breast cancer GLI1 is upregulated due to the loss of lysine methyltransferases (KMT) SETD7 which can put repressive marks on histones within GLI1 promoter and loss of these marks results in GLI1 overexpression [170]. Full-length, but not truncated, GLI3 protein can be methylated by SETD7 at K436 and K595 amino acid residues. This methylation increases stability and DNA-binding ability of GLI3 and consequently enhances the HH-GLI pathway activation, which was demonstrated in tumorigenesis of non-small cell lung cancer [171].

Recently it was discovered a non-coding three-exon RNA transcript positioned head-to-head with GLI1 gene. This antisense RNA (termed GLI1AS) negatively regulates expression of GLI1, which, on the contrary, as well as TGFB, positively regulates GLI1AS expression. GLI1AS causes local alterations of chromatin structure by increasing the silencing mark H3K27me3 and reducing the recruitment of RNA polymerase II to this locus, what leads to decreased GLI1 transcription. GLI1AS expression showed high positive correlation with GLI1 expression in basal cell carcinoma and breast cancer [172].

\subsubsection{RNA Interference}

The expression of miRNAs and their target genes are generally inversely correlated. GLI1 is regulated by miR-218 and miR-324-5p, which are both lost in MB [173-176]. In gastric cancer, GLI1 is upregulated due to the loss of miR-202-3b and miR-133b [177,178]. miR-218 downregulates GLI2, but miR-106b, which is overexpressed in MB and BCC, upregulates GLI2 [174,175,179-182]. GLI2 is targeted by miR-326 which is lost in non-small-cell lung cancer [183]. In hepatocellular carcinoma, GLI2 is upregulated due to the loss of miR-200a [184,185], while GLI3 due to the loss of miR-378a-3p [186]. GLI3 is upregulated in BCC because of the miR-378 loss, which controls expression of GLI3 in healthy tissue [179,186]. In gastric cancer GLI2 is upregulated due to the upregulation of lncRNA metastasis associated lung adenocarcinoma transcript 1 (MALAT1). MALAT1 downregulates miR-202 which normally targets GLI2 [187]. 


\section{GLI Proteins as Therapeutic Targets}

Targeting the HH-GLI signaling pathway is one of the recent approaches in cancer therapy. Originally, the HH-GLI signaling pathway was targeted at the level of SMO, in an attempt to bypass the inactivating PTCH1 and activating SMO mutations often found in Hedgehog-associated tumors like medulloblastoma and basal cell carcinoma. The first inhibitor, cyclopamine, was extracted from the Veratrum californicum plant after it was associated with congenital malformations in lambs feeding on this specific flower [188]. Cyclopamine was found to be inappropriate for clinical use due to poor solubility and pharmacokinetic properties [189]. Therefore, several companies started developing SMO inhibitors, and today some of those inhibitors are used in the clinic. GDC-0499, known as vismodegib, is used for treatment of advanced basal cell carcinoma [190,191]. NVP-LDE225 (sonidegib) has also been approved for locally advanced basal cell carcinoma treatment [192], while IPI-926 (saridegib) is still undergoing clinical trials [193]. All three SMO inhibitors are under investigation for treatment of solid tumors [194-196], and a known and approved antifungal drug itraconazole is being examined for potential clinical application for treatment of basal cell carcinoma [197]. Unfortunately, resistance to SMO inhibitors has already been reported in patients, with distinct mechanisms that include mutations in SMO, amplification of GLI2 or upregulation of synergistic signaling pathways such as PI3K. Gönissen et al. suggest some possible solutions in their review: second-generation SMO inhibitors with a different mechanism of action, HH-GLI pathway inhibitors downstream of SMO, or combination strategies with other signaling pathways [198]. Other HH-GLI inhibitors, targeting components downstream of SMO, have not yet been included in clinical trials.

\subsection{GLI Inhibitors}

Not all tumors with HH-GLI pathway activity show the canonical signal transduction. In those tumors, canonical SMO inhibition is not as effective because GLI proteins are activated regardless of SMO by other signaling cascades. That is the reason that the focus has been shifting from SMO inhibitors to GLI inhibitors. The first and most frequently used GLI inhibitors GANT58 and GANT61 were detected in a cell-based screen by Lauth et al., and GANT61 was shown to be more potent of the two [199]. Their advantage, compared to the SMO inhibitors, is inhibition of both canonical and non-canonical activation of GLI proteins. The same authors have also shown that GANT61 impairs GLI1-DNA binding [199], and this is due to direct binding of GANT61 to GLI1 protein. The binding site is conserved between GLI1 and GLI2 proteins, making GANT61 an inhibitor of both GLI1- and GLI2-mediated transcription [200].

The most commonly reported effect of GANT61 is decreased cell survival through induction of apoptosis. This has been demonstrated in numerous tumor models (Table 2). Other frequently reported effect is the G1/S phase cell cycle arrest [201]. Recently discovered additional effects of GANT61 include the induction of double strand breaks (DSB) [202], generation of reactive oxygen species (ROS) by the mitochondria [203], decreased induction of EMT [204] and induction of autophagy [205]. Treatment with GANT61 affects GLI target gene expression, such as human telomerase reverse transcriptase (TERT), additionally decreasing the proliferative potential of cells [206].

When comparing upstream canonical HH-GLI inhibition (SMO inhibition) with downstream inhibition (GLI inhibition), it is evident that downstream inhibition is more effective in tumor therapy, as shown by several authors in recent studies. For example, Benvenuto et al. compared the two types of inhibition on breast cancer growth in a nude mouse xenograft model, and demonstrated that the effect of GANT61 is more pronounced than GDC-0449 [207]. The same effect was demonstrated on a panel of 18 cell lines derived from the most common and aggressive pediatric tumors, where GANT61 inhibition was more effective than SANT1 [208]. Bleomycin-induced lung fibrosis was also found to be more responsive to GLI inhibition than SMO inhibition [209]. In a xenograft model of squamous lung cancer GANT61 was very effective while GDC-0449 resulted in limited cytotoxicity [210]. GANT61 was shown to be more potent that cyclopamine in rhabdomyosarcoma, both in vitro and in vivo [211], in neuroblastoma [201], in biliary tract tumors [212] and in chronic lymphocytic leukemia [213]. GANT61 is more potent than GDC-0449 in prostate cancer cells [214] and acute myeloid leukemia [215]. 
Table 2. List of GLI inhibitors and their effects in various tumors.

\begin{tabular}{|c|c|c|c|c|}
\hline Inhibitor & Mode of Action & Model/Samples & Effect & Reference \\
\hline \multicolumn{5}{|c|}{ Compounds affecting GLI activity } \\
\hline GANT58 & GLI antagonist & Acute T lymphocytic leukemia & Decreased cell viability, G1/S accumulation & [216] \\
\hline \multirow{15}{*}{ GANT61 } & \multirow{15}{*}{$\begin{array}{l}\text { Inhibition of GLI1/DNA and } \\
\text { GLI2/DNA binding }\end{array}$} & Colon carcinoma & Cytotoxicity, induction of DNA damage, G1/S accumulation & [202] \\
\hline & & $\begin{array}{l}\text { Large cell neuroendocrine } \\
\text { carcinoma of the lung }\end{array}$ & Inhibition of cell growth, sensitivity to cisplatin & [217] \\
\hline & & Prostate cancer & $\begin{array}{l}\text { Decreased cell viability, induction of apoptosis, downregulation of } \\
\text { stem cell markers }\end{array}$ & {$[214,218]$} \\
\hline & & Acute myeloid leukemia & $\begin{array}{l}\text { Inhibition of cell growth and colony formation, induction of } \\
\text { apoptosis }\end{array}$ & {$[215,219]$} \\
\hline & & Rhabdomyosarcoma & $\begin{array}{c}\text { Inhibition of xenograft growth, induction of apoptosis, } \\
\text { downregulation of EMT markers }\end{array}$ & [220] \\
\hline & & Neuroblastoma & $\begin{array}{l}\text { Decreased cell viability, induction of apoptosis, induction of } \\
\text { autophagy, inhibition of xenograft growth }\end{array}$ & {$[201,221]$} \\
\hline & & Ewing's sarcoma family tumor & Cytotoxicity, induction of apoptosis & [222] \\
\hline & & Ovarian cancer & Reduced migration and invasion, inhibition of xenograft growth & [223] \\
\hline & & Squamous lung cancer & $\begin{array}{c}\text { Inhibition of cell growth, induction of apoptosis, inhibition of } \\
\text { xenograft growth }\end{array}$ & [210] \\
\hline & & Pancreatic cancer stem cells & $\begin{array}{l}\text { Decreased cell viability, reduced migration, invasion and spheroid } \\
\text { formation, induction of apoptosis, inhibition of xenograft growth }\end{array}$ & [204] \\
\hline & & T-cell lymphoma & Decreased cell viability, induction of apoptosis & [224] \\
\hline & & Mesothelioma & Cytotoxicity, induction of apoptosis, G1 accumulation & [203] \\
\hline & & Biliary tract tumors & Cytotoxicity, induction of apoptosis & [212] \\
\hline & & Cervical cancer & $\begin{array}{l}\text { Reduction of proliferation and survival, induction of apoptosis, } \\
\text { generation of ROS }\end{array}$ & [225] \\
\hline & & Melanoma & $\begin{array}{c}\text { Decreased cell viability, induction of apoptosis, reduced colony } \\
\text { forming }\end{array}$ & [226] \\
\hline \multirow{5}{*}{ arsenic trioxide (ATO) } & \multirow{5}{*}{ Inhibition of GLI1/GLI2 activity } & Pancreatic cancer stem cells & Inhibition of cell growth, induction of apoptosis, reduced migration & [227] \\
\hline & & Medulloblastoma & Cytotoxicity, inhibition of xenograft growth & {$[228,229]$} \\
\hline & & Osteosarcoma & $\begin{array}{l}\text { Inhibition of cell growth, reduced colony forming, induction of } \\
\text { apoptosis, inhibition of xenograft growth }\end{array}$ & {$[230,231]$} \\
\hline & & Prostate & Inhibition of cell growth & [232] \\
\hline & & Rhabdoid tumors & Cytotoxicity, induction of apoptosis, inhibition of xenograft growth & [233] \\
\hline
\end{tabular}


Table 2. Cont.

\begin{tabular}{|c|c|c|c|c|}
\hline Inhibitor & Mode of Action & Model/Samples & Effect & Reference \\
\hline $\begin{array}{l}\text { cynanbungeigenin } \mathrm{C} \text { and } \mathrm{D} \\
\text { (CBC and CBD) }\end{array}$ & Gli1 antagonists & Medulloblastoma & Inhibition of allograft growth & [234] \\
\hline gedunin & GLI inhibition & Pancreatic cancer & $\begin{array}{l}\text { Inhibition of cell growth, induction of apoptosis, reduced migration, } \\
\text { downregulation of EMT markers, inhibition of xenograft growth }\end{array}$ & [235] \\
\hline GLI-I & GLI inhibitor & $\begin{array}{l}\text { Malignant pleural } \\
\text { mesothelioma }\end{array}$ & Cytotoxicity, induction of apoptosis, inhibition of xenograft growth & [236] \\
\hline glabrescione B & $\begin{array}{l}\text { Inhibition of GLI1/DNA } \\
\text { binding }\end{array}$ & $\begin{array}{l}\text { Medulloblastoma, basal cell } \\
\text { carcinoma }\end{array}$ & $\begin{array}{l}\text { Inhibition of cell growth, reduced spheroid formation, induction of } \\
\text { apoptosis, inhibition of allograft growth }\end{array}$ & [237] \\
\hline physalin $\mathrm{H}$ & $\begin{array}{l}\text { GLI1-DNA complex formation } \\
\text { inhibition }\end{array}$ & Pancreatic and prostate cancer & Cytotoxicity & [238] \\
\hline vitretrifolin D & $\begin{array}{l}\text { Inhibition of GLI1-DNA } \\
\text { binding }\end{array}$ & Prostate and pancreatic cancer & Cytotoxicity & [239] \\
\hline solasonine & GLI-mediated transcription & SHH-LIGHT2 reporter cells & downregulation of GLI1 and PTCH1 expression & [240] \\
\hline \multicolumn{5}{|c|}{ Compounds affecting GLI stability and trafficking } \\
\hline HPI-1-4 & $\begin{array}{l}\text { Different effects on GLI stability } \\
\text { and trafficking }\end{array}$ & Breast cancer & $\begin{array}{l}\text { Inhibition of cell growth, induction of apoptosis, reduced cancer stem } \\
\text { cell population, reduced migration }\end{array}$ & {$[241,242]$} \\
\hline aspirin & $\begin{array}{l}\text { Inhibits GLI1 translocation to } \\
\text { nucleus }\end{array}$ & Glioma & $\begin{array}{c}\text { Cytotoxicity, induction of apoptosis, reduced migration and invasion, } \\
\text { downregulation of EMT markers, }\end{array}$ & [243] \\
\hline \multicolumn{5}{|c|}{ Compounds affecting GLI expression } \\
\hline \multirow[b]{2}{*}{ genistein } & \multirow[b]{2}{*}{ GLI1 expression } & Gastric cancer & Downregulation of stem cell markers, reduced invasive capacity & [244] \\
\hline & & Breast cancer & $\begin{array}{l}\text { Inhibition of cell growth, reduced colony forming, induction of } \\
\text { apoptosis, inhibition of xenograft growth }\end{array}$ & [245] \\
\hline Quinolone-1-(2H)-ones & GLI expression & SHH-LIGHT2 reporter cells & Downregulation of GLI1 and PTCH1 expression & [246] \\
\hline compound 29a & GLI protein expression & Medulloblastoma & Inhibition of allograft growth & [247] \\
\hline \multicolumn{5}{|c|}{ Compounds affecting protein regulators of GLI activity } \\
\hline imiquimod & $\begin{array}{l}\text { PKA-mediated GLI } \\
\text { phosphorylation }\end{array}$ & $\begin{array}{l}\text { Murine asocellular carcinoma, } \\
\text { human medulloblastoma }\end{array}$ & Downregulation of GLI1 and HHIP expression, GLI3 processing & [248] \\
\hline forskolin & PKA activation & Pediatric tumors & Inhibition of cell growth, induction of apoptosis & [249] \\
\hline \multirow{2}{*}{ perifosine } & \multirow{2}{*}{$\begin{array}{l}\text { inhibition of GLI1 via } \\
\text { AKT/PI3K }\end{array}$} & Pancreatic cancer & PTCH1 downregulation, cytotoxicity, senzitization to gemcitabine & [250] \\
\hline & & Acute T cell leukemia & Cytotoxycity & [216] \\
\hline nanoquinacrine & activation of GSK3B & Oral cancer stem cells & Inhibition of cell growth, induction of apoptosis & [251] \\
\hline \multicolumn{5}{|c|}{ Epigenetic regulation of GLI activity } \\
\hline JQ1 & Inhibition of BET bromodomain & $\begin{array}{l}\text { medulloblastoma, basocellular } \\
\text { carcinoma }\end{array}$ & $\begin{array}{c}\text { Inhibition of cell growth, induction of apoptosis, inhibition of } \\
\text { allograft growth }\end{array}$ & [252] \\
\hline I-BET151 & Inhibition of BET bromodomain & medulloblastoma & Downregulation of GLI1, inhibition of allograft growth & [253] \\
\hline
\end{tabular}


Compounds affecting protein regulators of GLI activity have also been used (listed in Table 2). For example, HH-GLI pathway inhibitors (HPIs) identified by Hyman et al. act on GLI processing and ciliogenesis [241]. Imiquimod, a known Toll-like receptor 7/8 (TLR7/8) antagonist, acts on protein kinase A (PKA), which regulates GLI processing and phosphorylation. Upon treatment, processing is increased, as is phosphorylation of GLI2 and accumulation of GLI3R [248]. Perifosine, an AKT/PI3K inhibitor, downregulates GLI1 expression through the PI3K/AKT pathway [250]. Nanoquinacrine regulates GSK3B activity, which in turn regulates GLI proteins [251].

Other compounds already used in the clinic have also shown to be useful in GLI inhibition, for example arsenic trioxide (ATO) which is used for treatment of acute promyelocytic leukemia (APL). Yang et al. demonstrated that ATO therapy in APL patients leads to compete remission in $86 \%$ of cases, and these patients show a significant downregulation of GLI2 and SMO gene expression, and marginal downregulation of PTCH1 and GLI1 [254]. Beauchamp et al. have demonstrated that ATO treatment affects GLI1 protein activity without modifying its cellular localization, by direct binding to the protein [229]. On the other hand, Kim et al. have shown that ATO inhibits activation of GLI2 by preventing its transport from the primary cilium [228]. Han et al. have proposed that ATO may act as a HH-GLI pathway inhibitor by replacing the zinc ion in the GLI zinc finger proteins, rendering them inactive [227]. Histone deacetylase 6 (HDAC6) inhibitors are novel potential targets in Hedgehog-associated tumors, since HDAC6 can regulate GLI2 and GLI3 protein expression [255]. Even aspirin, a widely used analgesic, antipyretic and anti-inflammatory drug, has shown inhibitory effect on the HH-GLI signaling pathway, and it sensitizes malignant glioma cells to temozolomide therapy [243].

Epigenetic regulation of GLI activity has also been demonstrated. Bromodomain and extra terminal (BET) proteins, or BRD4 more specifically, binds directly to the GLI1 and GLI2 promoters and regulates their transcription. BRD4 inhibitors JQ1 and I-BET151 have been shown to inhibit HH-GLI signaling and tumor growth $[252,253]$.

One of the issues in treating solid tumors is delivery to target cells. Nanoparticles are being tested to improve the bioavailability and delivery of specific compounds. For example, glabrescione B was encapsulated into oil-cored polymeric nanocapsules by Ingallina et al, in an attempt to increase delivery of high doses of glabrescione B to solid tumors [256]. HH-GLI pathway inhibitor HPI-1 was encapsulated in nanoparticles from poly (lactic-co-glycolic acid) (PLGA) conjugated with polyethylene glycol (PEG) and successfully used in mouse models of medulloblastoma and pancreatic cancer xenografts [257].

Recently, several groups have started the search for better and novel GLI antagonists, mostly using high-throughput screens of various synthetic or natural compounds, but also virtual libraries. To date, several novel specific GLI antagonists have been identified: glabrescione B [237], physalin H [238], HPI-1 through -4 [241], vitretrifolin D [239], cynanbungeigenin C and D [234], and compound 29a [247].

\subsection{Combining GLI Inhibitors with other Chemotherapeutic Agents}

HH-GLI signaling pathway is a good target for possible combination treatment. Inhibition of this pathway with other oncogenic pathways often gives improved synergistic effects compared to individual therapy. Table 3 shows an overview of several studies examining combined effects of downstream Hedgehog inhibition with inhibition of other pathways, and in the majority of cases the effect is synergistic. It is interesting to note that in breast cancer cells, combined treatment of tamoxifen with SMO inhibitor exerts a different response that combined treatment with GANT61. In the case of cyclopamine, the cells show short-term survival while this is not the case when using GLI inhibitors [258,259]. 
Table 3. Combination therapies targeting GLI proteins in combination with other tumor therapies.

\begin{tabular}{|c|c|c|c|c|}
\hline Combination Therapy & Molecular Targets & Model & Effect & Reference \\
\hline $\mathrm{ATO}+$ radiotherapy & GLI + proliferation & $\begin{array}{l}\text { High grade neuroepithelial } \\
\text { tumor of the central nervous } \\
\text { system (primary culture and } \\
\text { patient) }\end{array}$ & Clinical remission for 6 months & [260] \\
\hline ATO + itraconazole & $\mathrm{GLI}+\mathrm{SMO}$ & $\begin{array}{l}\text { Patients with metastatic basal } \\
\text { cell carcinoma }\end{array}$ & $\begin{array}{l}\text { Best overall response was stable disease in } 3 / 5 \\
\text { patients }\end{array}$ & [261] \\
\hline GANT61 + obatoclax & GLI + BCL2 & Melanoma cells & Decreased cell viability, increased apoptosis & [226] \\
\hline GANT61 + sunitinib + PF-04691502 & GLI + FLT3 + PI3K & Acute myeloid leukemia & $\begin{array}{l}\text { Stronger anti-leukemic effects in vivo, prolonged } \\
\text { survival of mice }\end{array}$ & [262] \\
\hline GANT61 + antiestrogens & GLI + estrogen & ER+ breast cancer cell lines & Decreased cell growth & [263] \\
\hline GANT61 + metformin & GLI + gluconeogenesis & $\begin{array}{c}\text { Prostate cancer cells and } \\
\text { xenografts }\end{array}$ & $\begin{array}{l}\text { Decreased cell growth, enhanced radiation } \\
\text { response }\end{array}$ & [264] \\
\hline GANT61 + paclitaxel & GLI + spindle inhibition & $\begin{array}{c}\text { ER+ and triple negative breast } \\
\text { cancer }\end{array}$ & Decreased cell growth in TNBC & [265] \\
\hline GANT61 + temozolomide & $\begin{array}{l}\text { GLI + alkylation/ } \\
\text { methylation of DNA }\end{array}$ & Glioma cell lines & $\begin{array}{l}\text { Decreased cell growth, increased apoptosis, } \\
\text { GANT61 sensitizes cells to TMZ }\end{array}$ & {$[266,267]$} \\
\hline GANT61 + rapamycin & $\mathrm{GLI}+\mathrm{mTOR}$ & $\begin{array}{l}\text { Pancreatic cancer cell lines and } \\
\text { xenografts }\end{array}$ & Reduced sphere formation and cell viability & [268] \\
\hline curcumin + resveratrol & HH-GLI signaling & $\begin{array}{l}\text { Breast cancer cell lines and } \\
\text { xenografts }\end{array}$ & $\begin{array}{l}\text { Induction of apoptosis, } 10 \text {-fold lower } \mathrm{IC}_{50} \text { doses in } \\
\text { combination compared to individual treatments }\end{array}$ & [269] \\
\hline ATO + LY294002 & GLI + PI3K & Colon carcinoma cells & Decreased proliferation, synergistic effect & {$[270]$} \\
\hline GANT58 + perifosine & GLI + AKT/PI3K & Acute $\mathrm{T}$ cell leukemia & Synergistic cytotoxic effect & [216] \\
\hline GANT61 + rapamycin & $\mathrm{GLI}+\mathrm{mTOR}$ & Myeloid leukemia & Growth arrest and apoptosis, synergistic effect & [271] \\
\hline GANT61 + itraconazole & GLI + antifungal & Breast cancer cell lines & Synergistically enhanced cytotoxicity & [272] \\
\hline GANT61 + PI103 & $\mathrm{GLI}+\mathrm{PI} 3 \mathrm{~K} / \mathrm{mTOR}$ & $\begin{array}{l}\text { Rhabdomyosarcoma cell lines } \\
\text { and xenografts }\end{array}$ & $\begin{array}{l}\text { Synergistic apoptosis induction and tumor growth } \\
\text { reduction }\end{array}$ & [273] \\
\hline GANT61 + trastuzumab + BEZ235 & $\begin{array}{c}\text { GLI + } \\
\text { ErbB2-PI3K-mTORC1 }\end{array}$ & Esophageal carcinoma & $\begin{array}{l}\text { Significantly stronger tumor reduction then } \\
\text { individual treatments }\end{array}$ & [274] \\
\hline GANT61 + irradiated riboflavin (iRF) & GLI + photosensitizer & $\begin{array}{l}\text { Melanoma cells and mouse } \\
\text { model }\end{array}$ & Potentiates the antiproliferative effect of iRF & [275] \\
\hline $\begin{array}{l}\text { GANT61 + cisplatin/doxorubicin/ } \\
\text { Irinotecan/vincristine }\end{array}$ & $\begin{array}{l}\text { GLI + standard } \\
\text { chemotherapy }\end{array}$ & Neuroblastoma & $\begin{array}{l}\text { Synergistic (doxorubicin or vincristine) or additive } \\
\text { effects (cisplatin or irinotecan) }\end{array}$ & [201] \\
\hline
\end{tabular}


Table 3. Cont

\begin{tabular}{cccc}
\hline Combination Therapy & Molecular Targets & Model & Effect \\
\hline GANT61 + cisplatin & $\begin{array}{c}\text { GLI + standard } \\
\text { chemotherapy }\end{array}$ & Biliary tract cancer & Synergistic effect \\
\hline GANT61 + rapamycin/temsirolimus & GLI + mTOR & Rhabdomyosarcoma & $\begin{array}{l}\text { Reduced survival compared to individual } \\
\text { treatments }\end{array}$ \\
\hline $\begin{array}{c}\text { ATO + cis-platin/ifosfamide/ } \\
\text { doxorubicin + vismodegib }\end{array}$ & $\begin{array}{c}\text { GLI + standard } \\
\text { chemotherapy + SMO }\end{array}$ & Osteosarcoma & $\begin{array}{l}\text { Synergistic effect, inhibition of tumor growth } \\
\text { in vivo }\end{array}$ \\
\hline nanoHHI + gemcitabine & GLI + nucleoside synthesis & Pancreatic cancer & Inhibition of tumor growth in vivo \\
\hline ATO + cyclopamine & GLI + SMO & Prostate cancer & $\begin{array}{l}\text { Synergistic effect, inhibition of tumor growth } \\
\text { in vivo }\end{array}$ \\
\hline ATO + LY294002 & GLI + PI3K & Colon cancer cells & Synergistic effect \\
\hline ATO + gemcitabine & GLI + nucleoside synthesis & $\begin{array}{c}\text { Pancreatic cancer cell lines and } \\
\text { xenografts }\end{array}$ & $\begin{array}{l}\text { Synergistic effect, inhibition of tumor growth } \\
\text { in vivo }\end{array}$ \\
\hline [232]
\end{tabular}




\subsection{Role of GLI Proteins in Chemoresistance}

GLI protein expression is often associated with resistance to chemotherapeutics, and loss of GLI, either chemically or by knockdown, re-sensitizes the cells to chemotherapy (Table 4). For example, in glioma cells, GLI1 induces non-canonical temozolomide resistance and its knockdown or treatment with aspirin re-sensitizes the cells to the drug [243]. In pancreatic cancer cells GLI1 knockdown, perifosine treatment or GANT61 treatment sensitize the cells to gemcitabine. Perifosine showed the same sensitizing effect to gemcitabine treatment in vivo on pancreatic tumor xenografts [250]. In large cell neuroendocrine carcinoma, downregulation of GLI1/2 sensitizes cells to cisplatin [217].

Table 4. Resistance mechanisms mediated by GLI in various tumors.

\begin{tabular}{|c|c|c|c|}
\hline Tumor Type & Resistant to: & Resistance Mechanism & Reference \\
\hline \multirow{5}{*}{ Lung cancer } & Staurosporine & $\begin{array}{l}\text { GLI1-mediated upregulation of NDRG1 and } \\
\text { downregulation of c-MYC and N-MYC }\end{array}$ & [276] \\
\hline & Gefitinib & $\begin{array}{l}\begin{array}{l}\text { Upregulation of SHH, SMO and GLI1 (reversible by } \\
\text { sulforaphane) }\end{array}\end{array}$ & [277] \\
\hline & $\begin{array}{c}\text { Platinum and } \\
\text { gefitinib/erlotinib }\end{array}$ & MEOX-2-dependent GLI1 upregulation & [278] \\
\hline & Platinum & Hedgehog pathway activation & [279] \\
\hline & EGFR inhibitors & $\begin{array}{l}\text { GLI1-mediated upregulation of SOX2, induction of } \\
\text { EMT }\end{array}$ & {$[105,280]$} \\
\hline $\begin{array}{l}\text { Lung and colorectal } \\
\text { cancer }\end{array}$ & Topoisomerase inhibitors & GLI1-mediated upregulation of BID & [281] \\
\hline \multirow{2}{*}{ Colorectal cancer } & 5-Fluorouracil & Upregulation of GLI1 and GLI2 and their targets & [282] \\
\hline & Vorinostat & GLI1-mediated upregulation of BCL2L1 & [283] \\
\hline \multirow{3}{*}{ Gastrointestinal cancer } & 5-Fluorouracil, cisplatin & GLI2-mediated upregulation of ABCG2 transporter & {$[284,285]$} \\
\hline & Doxorubicin & GLI2-mediated upregulation of ABCG2 transporter & [286] \\
\hline & Imatinib & GLI-mediated upregulation of KIT & [287] \\
\hline Esophageal cancer & Chemoradiation & Nuclear localization of GLI1 & [288] \\
\hline Hepatocellular cancer & Sorafenib & GLI2-mediated upregulation of $\mathrm{ABCC} 1$ transporter & [289] \\
\hline Glioblastoma & Temozolomide & GLI1-mediated upregulation of MGMT & {$[290,291]$} \\
\hline $\begin{array}{l}\text { Clear cell renal } \\
\text { carcinoma }\end{array}$ & Sunitinib & GLI2 overexpression & [292] \\
\hline Ovarian cancer & Cisplatin & $\begin{array}{l}\text { Rab23-mediated upregulation of ABCG2 through } \\
\text { GLI1 }\end{array}$ & {$[293,294]$} \\
\hline Basal cell carcinoma & Gdc-619 & SRF-mediated upregulation of GLI1 & [295] \\
\hline $\begin{array}{l}\text { Head and neck } \\
\text { squamous cancer }\end{array}$ & Radioresistance & mTOR/SK6-mediated upregulation of GLI1 & [296] \\
\hline \multirow[b]{2}{*}{ Multiple myeloma } & Lenalidomide & ADAR1-dependent RNA editing of GLI1 & [144] \\
\hline & Bortezomib & $\begin{array}{l}\text { Downregulation of mir-324-5p leading to } \\
\text { upregulation of SMO and GLI1 }\end{array}$ & [297] \\
\hline $\begin{array}{l}\text { Chronic myeloid } \\
\text { leukemia }\end{array}$ & Imatinib & $\begin{array}{l}\text { GLI1-mediated upregulation of BCR-ABL, p-Akt, } \\
\text { Bcl-xl and survivin (reversible by oroxyloside A) }\end{array}$ & [298] \\
\hline \multirow[b]{2}{*}{ Acute myeloid leukemia } & Radiation & Activation of the GLI1/PI3K/AKT/NFKB pathway & [299] \\
\hline & Ribavirin/cytarabine & $\begin{array}{l}\text { GLI1-mediated upregulation of UDP-glucuronosyl } \\
\text { transferase enzymes }\end{array}$ & [300] \\
\hline
\end{tabular}

The mechanism by which GLI proteins impart resistance in still not elucidated. Subpopulations of cells remaining after therapy often show upregulation of the HH-GLI signaling pathway, and these resistant cells repopulate the tumor mass and generate treatment-resistant tumors. Most commonly detected mechanism is the aberrant activation of the $A B C$ transporters, which can be regulated by the HH-GLI signaling pathway [301]. Another proposed mechanisms is induction of the glucuronidation in acute myeloid leukemia (AML), where GLI1 is sufficient to drive UGT1A-dependent glucuronidation of ribavirin and cytarabine, leading to resistance [300]. Resistance to cisplatin is imparted by enhanced 
DNA repair, and by changing cellular accumulation of the drug through modulation of the c-Jun phosphorylation cascade [302].

\section{Conclusions}

The HH-GLI signaling pathway is a biologically important pathway regulating development, stemness, wound healing and cell survival. It is a tightly regulated system which in the adult organism remains active only in the stem cell population. Major effector of the pathway are the GLI proteins, which can act as activators or repressors depending on the context. Mutations, epigenetic changes or non-canonical activation leading to upregulation of GLI proteins have been associated with numerous congenital malformations and tumors. Therefore, GLI proteins have become attractive molecular targets for novel tumor therapies, since the pathway has been associated with one third of all tumor types. The major problem in tumor therapy today is development of resistance, even to targeted therapies. It is believed that a small subpopulation of tumor cells reacts to therapy by activating numerous signaling pathways in an effort to survive. One of the mechanisms is the activation of HH-GLI signaling pathway, mostly non-canonically through other signals affecting GLI proteins. Consequences of crosstalk between HH-GLI and other pro-tumorigenic pathways include activation of a positive feedback loop, in which activation or accumulation of a component from the first pathway leads to the activation or accumulation of another component, which creates a vicious cycle enhancing cancer progression. For that reason, research focus has shifted toward discovery of successful combined targeted therapies that should be applied in the early stages of disease.

Acknowledgments: This work was supported by the Croatian Science Foundation research grant no. IP-2016-06-1268 and the City of Zagreb grant no. URBROJ: 251-03-02-15-2.

Conflicts of Interest: The authors declare no conflict of interest.

\section{References}

1. Nüsslein-Volhard, C.; Wieschaus, E. Mutations affecting segment number and polarity in Drosophila. Nature 1980, 287, 795-801. [CrossRef] [PubMed]

2. Bhardwaj, G.; Murdoch, B.; Wu, D.; Baker, D.P.; Williams, K.P.; Chadwick, K.; Ling, L.E.; Karanu, F.N.; Bhatia, M. Sonic hedgehog induces the proliferation of primitive human hematopoietic cells via BMP regulation. Nat. Immunol. 2001, 2, 172-180. [CrossRef] [PubMed]

3. Merchant, A.; Joseph, G.; Wang, Q.; Brennan, S.; Matsui, W. Gli1 regulates the proliferation and differentiation of HSCs and myeloid progenitors. Blood 2010, 115, 2391-2396. [CrossRef] [PubMed]

4. Lau, C.; Outram, S.V.; Saldaña, J.I.; Furmanski, A.L.; Dessens, J.T.; Crompton, T. Regulation of murine normal and stress-induced erythropoiesis by Desert Hedgehog (Dhh). Blood 2012. [CrossRef] [PubMed]

5. Outram, S.V.; Varas, A.; Pepicelli, C.V.; Crompton, T. Hedgehog signaling regulates differentiation from double-negative to double-positive thymocyte. Immunity 2000, 13, 187-197. [CrossRef]

6. Rowbotham, N.J.; Hager-Theodorides, A.L.; Cebecauer, M.; Shah, D.K.; Drakopoulou, E.; Dyson, J.; Outram, S.V.; Crompton, T. Activation of the Hedgehog signaling pathway in T-lineage cells inhibits TCR repertoire selection in the thymus and peripheral T-cell activation. Blood 2007, 109, 3757-3766. [CrossRef] [PubMed]

7. Furmanski, A.L.; Saldana, J.I.; Ono, M.; Sahni, H.; Paschalidis, N.; D'Acquisto, F.; Crompton, T. Tissue-Derived Hedgehog Proteins Modulate Th Differentiation and Disease. J. Immunol. 2013, 190, 2641-2649. [CrossRef] [PubMed]

8. Hager-Theodorides, A.L.; Furmanski, A.L.; Ross, S.E.; Outram, S.V.; Rowbotham, N.J.; Crompton, T. The Gli3 Transcription Factor Expressed in the Thymus Stroma Controls Thymocyte Negative Selection via Hedgehog-Dependent and -Independent Mechanisms. J. Immunol. 2009, 183, 3023-3032. [CrossRef] [PubMed]

9. Tukachinsky, H.; Lopez, L.V.; Salic, A. A mechanism for vertebrate Hedgehog signaling: Recruitment to cilia and dissociation of SuFu-Gli protein complexes. J. Cell Biol. 2010, 191, 415-428. [CrossRef] [PubMed] 
10. Huangfu, D.; Anderson, K.V. Cilia and Hedgehog responsiveness in the mouse. Proc. Natl. Acad. Sci. USA 2005, 102, 11325-11330. [CrossRef] [PubMed]

11. Wheway, G.; Nazlamova, L.; Hancock, J.T. Signaling through the Primary Cilium. Front. Cell Dev. Biol. 2018, 6. [CrossRef] [PubMed]

12. Rohatgi, R.; Milenkovic, L.; Scott, M.P. Patched1 Regulates Hedgehog Signaling at the Primary Cilium. Science 2007, 317, 372-376. [CrossRef] [PubMed]

13. Sasaki, H.; Nishizaki, Y.; Hui, C.; Nakafuku, M.; Kondoh, H. Regulation of Gli2 and Gli3 activities by an amino-terminal repression domain: Implication of Gli2 and Gli3 as primary mediators of Shh signaling. Development 1999, 126, 3915-3924. [PubMed]

14. Hui, C.; Angers, S. Gli Proteins in development and disease. Annu. Rev. Cell Dev. Biol. 2011, 27, $513-537$. [CrossRef] [PubMed]

15. Mathew, E.; Zhang, Y.; Holtz, A.M.; Kane, K.T.; Song, J.Y.; Allen, B.L.; Pasca di Magliano, M. Dosage-dependent regulation of pancreatic cancer growth and angiogenesis by hedgehog signaling. Cell Rep. 2014, 9, 484-494. [CrossRef] [PubMed]

16. Briscoe, J.; Thérond, P.P. The mechanisms of Hedgehog signalling and its roles in development and disease. Nat. Rev. Mol. Cell Biol. 2013, 14, 418-431. [CrossRef] [PubMed]

17. Chuang, P.T.; McMahon, A.P. Vertebrate Hedgehog signalling modulated by induction of a Hedgehog-binding protein. Nature 1999, 397, 617-620. [CrossRef] [PubMed]

18. Kwong, L.; Bijlsma, M.F.; Roelink, H. Shh-mediated degradation of Hhip allows cell autonomous and non-cell autonomous Shh signaling. Nat. Commun. 2014, 5, 4849. [CrossRef] [PubMed]

19. Sharpe, H.J.; Wang, W.; Hannoush, R.N.; de Sauvage, F.J. Regulation of the oncoprotein Smoothened by small molecules. Nat. Chem. Biol. 2015, 11, 246-255. [CrossRef] [PubMed]

20. Byrne, E.F.X.; Sircar, R.; Miller, P.S.; Hedger, G.; Luchetti, G.; Nachtergaele, S.; Tully, M.D.; Mydock-McGrane, L.; Covey, D.F.; Rambo, R.P.; et al. Structural basis of Smoothened regulation by its extracellular domains. Nature 2016, 535, 517-522. [CrossRef] [PubMed]

21. Huang, P.; Nedelcu, D.; Watanabe, M.; Jao, C.; Kim, Y.; Liu, J.; Salic, A. Cellular Cholesterol Directly Activates Smoothened in Hedgehog Signaling. Cell 2016, 166, 1176-1187. [CrossRef] [PubMed]

22. Myers, B.R.; Neahring, L.; Zhang, Y.; Roberts, K.J.; Beachy, P.A. Rapid, direct activity assays for Smoothened reveal Hedgehog pathway regulation by membrane cholesterol and extracellular sodium. Proc. Natl. Acad. Sci. USA 2017, 114, E11141-E11150. [CrossRef] [PubMed]

23. Huang, P.; Zheng, S.; Wierbowski, B.M.; Kim, Y.; Nedelcu, D.; Aravena, L.; Liu, J.; Kruse, A.C.; Salic, A. Structural Basis of Smoothened Activation in Hedgehog Signaling. Cell 2018, 174, 312-324. [CrossRef] [PubMed]

24. Byrne, E.F.; Luchetti, G.; Rohatgi, R.; Siebold, C. Multiple ligand binding sites regulate the Hedgehog signal transducer Smoothened in vertebrates. Curr. Opin. Cell Biol. 2018, 51, 81-88. [CrossRef] [PubMed]

25. Luchetti, G.; Sircar, R.; Kong, J.H.; Nachtergaele, S.; Sagner, A.; Byrne, E.F.; Covey, D.F.; Siebold, C.; Rohatgi, R. Cholesterol activates the G-protein coupled receptor Smoothened to promote Hedgehog signaling. eLife 2016, 5, e20304. [CrossRef] [PubMed]

26. Jiang, K.; Liu, Y.; Fan, J.; Zhang, J.; Li, X.-A.; Evers, B.M.; Zhu, H.; Jia, J. PI(4)P Promotes Phosphorylation and Conformational Change of Smoothened through Interaction with Its C-terminal Tail. PLoS Biol. 2016, 14, e1002375. [CrossRef] [PubMed]

27. Chen, Y.; Jiang, J. Decoding the phosphorylation code in Hedgehog signal transduction. Cell Res. 2013, 23, 186-200. [CrossRef] [PubMed]

28. Chen, Y.; Yue, S.; Xie, L.; Pu, X.-H.; Jin, T.; Cheng, S.Y. Dual Phosphorylation of Suppressor of Fused (Sufu) by PKA and GSK3 Regulates Its Stability and Localization in the Primary Cilium. J. Biol. Chem. 2011, 286, 13502-13511. [CrossRef] [PubMed]

29. Mukhopadhyay, S.; Wen, X.; Ratti, N.; Loktev, A.; Rangell, L.; Scales, S.J.; Jackson, P.K. The ciliary G-protein-coupled receptor Gpr161 negatively regulates the Sonic hedgehog pathway via cAMP signaling. Cell 2013, 152, 210-223. [CrossRef] [PubMed]

30. Pal, K.; Hwang, S.; Somatilaka, B.; Badgandi, H.; Jackson, P.K.; DeFea, K.; Mukhopadhyay, S. Smoothened determines $\beta$-arrestin-mediated removal of the $G$ protein-coupled receptor Gpr161 from the primary cilium. J. Cell Biol. 2016, 212, 861-875. [CrossRef] [PubMed] 
31. Pusapati, G.V.; Kong, J.H.; Patel, B.B.; Gouti, M.; Sagner, A.; Sircar, R.; Luchetti, G.; Ingham, P.W.; Briscoe, J.; Rohatgi, R. G protein-coupled receptors control the sensitivity of cells to the morphogen Sonic Hedgehog. Sci. Signal. 2018, 11, eaao5749. [CrossRef] [PubMed]

32. Yang, C.; Chen, W.; Chen, Y.; Jiang, J. Smoothened transduces Hedgehog signal by forming a complex with Evc/Evc2. Cell Res. 2012, 22, 1593-1604. [CrossRef] [PubMed]

33. Dorn, K.V.; Hughes, C.E.; Rohatgi, R. A Smoothened-Evc2 complex transduces the Hedgehog signal at primary cilia. Dev. Cell 2012, 23, 823-835. [CrossRef] [PubMed]

34. Musgrove, E.A.; Sutherland, R.L. Biological determinants of endocrine resistance in breast cancer. Nat. Rev. Cancer 2009, 9, 631-643. [CrossRef] [PubMed]

35. Ramaswamy, B.; Lu, Y.; Teng, K.-Y.; Nuovo, G.; Li, X.; Shapiro, C.L.; Majumder, S. Hedgehog Signaling Is a Novel Therapeutic Target in Tamoxifen-Resistant Breast Cancer Aberrantly Activated by PI3K/AKT Pathway. Cancer Res. 2012, 72, 5048-5059. [CrossRef] [PubMed]

36. Liu, X.; Wang, X.; Du, W.; Chen, L.; Wang, G.; Cui, Y.; Liu, Y.; Dou, Z.; Wang, H.; Zhang, P.; et al. Suppressor of fused (Sufu) represses Gli1 transcription and nuclear accumulation, inhibits glioma cell proliferation, invasion and vasculogenic mimicry, improving glioma chemo-sensitivity and prognosis. Oncotarget 2014, 5, 11681. [CrossRef] [PubMed]

37. Shi, Q.; Han, Y.; Jiang, J. Suppressor of fused impedes Ci/Gli nuclear import by opposing Trn/Kap $\beta 2$ in Hedgehog signaling. J. Cell Sci. 2014, 127, 1092-1103. [CrossRef] [PubMed]

38. Tempe, D.; Casas, M.; Karaz, S.; Blanchet-Tournier, M.-F.; Concordet, J.-P. Multisite Protein kinase A and Glycogen synthase kinase 3 beta phosphorylation leads to Gli3 ubiquitination by SCF bTrCP. Mol. Cell. Biol. 2006, 26, 4316-4326. [CrossRef] [PubMed]

39. Wang, B.; Li, Y. Evidence for the direct involvement of \{beta\}TrCP in Gli3 protein processing. Proc. Natl. Acad. Sci. USA 2006, 103, 33-38. [CrossRef] [PubMed]

40. Pan, Y.; Bai, C.B.; Joyner, A.L.; Wang, B. Sonic hedgehog signaling regulates Gli2 transcriptional activity by suppressing its processing and degradation. Mol. Cell. Biol. 2006, 26, 3365-3377. [CrossRef] [PubMed]

41. Wang, B.; Fallon, J.F.; Beachy, P.A. Hedgehog-regulated processing of Gli3 produces an anterior/posterior repressor gradient in the developing vertebrate limb. Cell 2000, 100, 423-434. [CrossRef]

42. Wang, C.; Pan, Y.; Wang, B. Suppressor of fused and Spop regulate the stability, processing and function of Gli2 and Gli3 full-length activators but not their repressors. Development 2010, 137, 2001-2009. [CrossRef] [PubMed]

43. Huang, D.; Wang, Y.; Tang, J.; Luo, S. Molecular mechanisms of suppressor of fused in regulating the hedgehog signalling pathway. Oncol. Lett. 2018, 15, 6077-6086. [CrossRef] [PubMed]

44. Cheng, S.Y.; Bishop, J.M. Suppressor of Fused represses Gli-mediated transcription by recruiting the SAP18-mSin3 corepressor complex. Proc. Natl. Acad. Sci. USA 2002, 99, 5442-5447. [CrossRef] [PubMed]

45. Paces-Fessy, M.; Boucher, D.; Petit, E.; Paute-Briand, S.; Blanchet-Tournier, M.-F. The negative regulator of Gli, Suppressor of fused (Sufu), interacts with SAP18, Galectin3 and other nuclear proteins. Biochem. J. 2004, 378, 353-362. [CrossRef] [PubMed]

46. Lin, C.; Yao, E.; Wang, K.; Nozawa, Y.; Shimizu, H.; Johnson, J.R.; Chen, J.-N.; Krogan, N.J.; Chuang, P.-T. Regulation of Sufu activity by $\mathrm{p} 66 \beta$ and Mycbp provides new insight into vertebrate Hedgehog signaling. Genes Dev. 2014, 28, 2547-2563. [CrossRef] [PubMed]

47. Kinzler, K.W.; Vogelstein, B. The GLI gene encodes a nuclear protein which binds specific sequences in the human genome. Mol. Cell. Biol. 1990, 10, 634-642. [CrossRef] [PubMed]

48. Winklmayr, M.; Schmid, C.; Laner-Plamberger, S.; Kaser, A.; Aberger, F.; Eichberger, T.; Frischauf, A.M. Non-consensus GLI binding sites in Hedgehog target gene regulation. BMC Mol. Biol. 2010, 11, 2. [CrossRef] [PubMed]

49. Katoh, Y.; Katoh, M. Hedgehog target genes: Mechanisms of carcinogenesis induced by aberrant hedgehog signaling activation. Curr. Mol. Med. 2009, 9, 873-886. [CrossRef] [PubMed]

50. Pandolfi, S.; Stecca, B. Cooperative integration between HEDGEHOG-GLI signalling and other oncogenic pathways: Implications for cancer therapy. Expert Rev. Mol. Med. 2015, 17. [CrossRef] [PubMed]

51. Ruiz i Altaba, A.; Mas, C.; Stecca, B. The Gli code: An information nexus regulating cell fate, stemness and cancer. Trends Cell Biol. 2007, 17, 438-447. [CrossRef] [PubMed]

52. Stecca, B.; Ruiz i Altaba, A. Context-dependent Regulation of the GLI Code in Cancer by HEDGEHOG and Non-HEDGEHOG Signals. J. Mol. Cell Biol. 2010, 2, 84-95. [CrossRef] [PubMed] 
53. Aberger, F.; Ruiz i Altaba, A. Context-dependent signal integration by the GLI code: The oncogenic load, pathways, modifiers and implications for cancer therapy. Semin. Cell Dev. Biol. 2014, 33, 93-104. [CrossRef] [PubMed]

54. Carpenter, R.L.; Lo, H.-W. Hedgehog pathway and GLI1 isoforms in human cancer. Discov. Med. 2012, 13, 105. [PubMed]

55. Speek, M.; Njunkova, O.; Pata, I.; Valdre, E.; Kogerman, P. A potential role of alternative splicing in the regulation of the transcriptional activity of human GLI 2 in gonadal tissues. BMC Mol. Biol. 2006, 7, 13. [CrossRef] [PubMed]

56. McCleary-Wheeler, A.L. From Normal Development to Disease: The Biochemistry and Regulation of GLI2. MEE 2014, 2, 1-19. [CrossRef]

57. Démurger, F.; Ichkou, A.; Mougou-Zerelli, S.; Le Merrer, M.; Goudefroye, G.; Delezoide, A.-L.; Quélin, C.; Manouvrier, S.; Baujat, G.; Fradin, M.; et al. New insights into genotype-phenotype correlation for GLI3 mutations. Eur. J. Hum. Genet. 2015, 23, 92-102. [CrossRef] [PubMed]

58. Kalff-Suske, M.; Wild, A.; Topp, J.; Wessling, M.; Jacobsen, E.M.; Bornholdt, D.; Engel, H.; Heuer, H.; Aalfs, C.M.; Ausems, M.G.; et al. Point mutations throughout the GLI3 gene cause Greig cephalopolysyndactyly syndrome. Hum. Mol. Genet. 1999, 8, 1769-1777. [CrossRef] [PubMed]

59. Amable, L.; Gavin, E.; Kudo, K.; Meng, E.; Rocconi, R.P.; Shevde, L.A.; Reed, E. GLI1 upregulates C-JUN through a specific 130-kDa isoform. Int. J. Oncol. 2014, 44, 655-661. [CrossRef] [PubMed]

60. Shimokawa, T.; Tostar, U.; Lauth, M.; Palaniswamy, R.; Kasper, M.; Toftgård, R.; Zaphiropoulos, P.G. Novel human glioma-associated oncogene 1 (GLI1) splice variants reveal distinct mechanisms in the terminal transduction of the hedgehog signal. J. Biol. Chem. 2008, 283, 14345-14354. [CrossRef] [PubMed]

61. Lo, H.-W.; Zhu, H.; Cao, X.; Aldrich, A.; Ali-Osman, F. A Novel Splice Variant of GLI1 That Promotes Glioblastoma Cell Migration and Invasion. Cancer Res. 2009, 69, 6790-6798. [CrossRef] [PubMed]

62. Cao, X.; Geradts, J.; Dewhirst, M.W.; Lo, H.-W. Upregulation of VEGF-A and CD24 gene expression by the tGLI1 transcription factor contributes to the aggressive behavior of breast cancer cells. Oncogene 2012, 31, 104-115. [CrossRef] [PubMed]

63. Ruiz i Altaba, A. Gli proteins encode context-dependent positive and negative functions: Implications for development and disease. Development 1999, 126, 3205-3216. [PubMed]

64. Stecca, B.; Ruiz i Altaba, A. A GLI1-p53 inhibitory loop controls neural stem cell and tumour cell numbers. EMBO J. 2009, 28, 663-676. [CrossRef] [PubMed]

65. Roessler, E.; Ermilov, A.N.; Grange, D.K.; Wang, A.; Grachtchouk, M.; Dlugosz, A.A.; Muenke, M. A previously unidentified amino-terminal domain regulates transcriptional activity of wild-type and disease-associated human GLI2. Hum. Mol. Genet. 2005, 14, 2181-2188. [CrossRef] [PubMed]

66. Ingham, P.W. Hedgehog signaling in animal development: Paradigms and principles. Genes Dev. 2001, 15, 3059-3087. [CrossRef] [PubMed]

67. Matise, M.P.; Joyner, A.L. Gli genes in development and cancer. Oncogene 1999, 18, 7852-7859. [CrossRef] [PubMed]

68. Theil, T.; Kaesler, S.; Grotewold, L.; Böse, J.; Rüther, U. Gli genes and limb development. Cell Tissue Res. 1999, 296, 75-83. [CrossRef] [PubMed]

69. Park, H.L.; Bai, C.; Platt, K.A.; Matise, M.P.; Beeghly, A.; Hui, C.C.; Nakashima, M.; Joyner, A.L. Mouse Gli1 mutants are viable but have defects in SHH signaling in combination with a Gli2 mutation. Development 2000, 127, 1593-1605. [PubMed]

70. Drakopoulou, E.; Outram, S.V.; Rowbotham, N.J.; Ross, S.E.; Furmanski, A.L.; Saldana, J.I.; Hager-Theodorides, A.L.; Crompton, T. Non-redundant role for the transcription factor Gli1 at multiple stages of thymocyte development. Cell Cycle 2010, 9, 4144-4152. [CrossRef] [PubMed]

71. Rowbotham, N.J.; Hager-Theodorides, A.L.; Furmanski, A.L.; Ross, S.E.; Outram, S.V.; Dessens, J.T.; Crompton, T. Sonic hedgehog negatively regulates pre-TCR-induced differentiation by a Gli2-dependent mechanism. Blood 2009, 113, 5144-5156. [CrossRef] [PubMed]

72. Lebel, M.; Mo, R.; Shimamura, K.; Hui, C. Gli2 and Gli3 play distinct roles in the dorsoventral patterning of the mouse hindbrain. Dev. Biol. 2007, 302, 345-355. [CrossRef] [PubMed]

73. Bear, K.A.; Solomon, B.D.; Antonini, S.; Arnhold, I.J.P.; França, M.M.; Gerkes, E.H.; Grange, D.K.; Hadley, D.W.; Jääskeläinen, J.; Paulo, S.S.; et al. Pathogenic mutations in GLI2 cause a specific phenotype that is distinct from holoprosencephaly. J. Med. Genet. 2014, 51, 413-418. [CrossRef] [PubMed] 
74. Hager-Theodorides, A.L.; Dessens, J.T.; Outram, S.V.; Crompton, T. The transcription factor Gli3 regulates differentiation of fetal CD4-CD8-Double Negative thymocytes. Blood 2005, 106, 1296-1304. [CrossRef] [PubMed]

75. Solanki, A.; Yanez, D.C.; Ross, S.; Lau, C.-I.; Papaioannou, E.; Li, J.; Saldaña, J.I.; Crompton, T. In the fetal thymus, Gli3 in thymic epithelial cells promotes thymocyte positive selection and differentiation by repression of Shh. Development 2018. [CrossRef] [PubMed]

76. Solanki, A.; Lau, C.-I.; Saldaña, J.I.; Ross, S.; Crompton, T. The transcription factor Gli3 promotes B cell development in fetal liver through repression of Shh. J. Exp. Med. 2017, 214, 2041-2058. [CrossRef] [PubMed]

77. Büscher, D.; Rüther, U. Expression profile of Gli family members and Shh in normal and mutant mouse limb development. Dev. Dyn. 1998, 211, 88-96. [CrossRef]

78. Ahmed, H.; Akbari, H.; Emami, A.; Akbari, M.R. Genetic Overview of Syndactyly and Polydactyly. Plast. Reconstr. Surg. Glob. Open 2017, 5, e1549. [CrossRef] [PubMed]

79. Wang, Z.; Wang, J.; Li, Y.; Geng, J.; Fu, Q.; Xu, Y.; Shen, Y. Novel frame-shift mutations of GLI3 gene in non-syndromic postaxial polydactyly patients. Clin. Chim. Acta 2014, 433, 195-199. [CrossRef] [PubMed]

80. Palencia-Campos, A.; Ullah, A.; Nevado, J.; Yildirim, R.; Unal, E.; Ciorraga, M.; Barruz, P.; Chico, L.; Piceci-Sparascio, F.; Guida, V.; et al. GLI1 inactivation is associated with developmental phenotypes overlapping with Ellis-van Creveld syndrome. Hum. Mol. Genet. 2017, 26, 4556-4571. [CrossRef] [PubMed]

81. Cohen, M.M. Holoprosencephaly: Clinical, anatomic, and molecular dimensions. Birth Defects Res. Part A Clin. Mol. Teratol. 2006, 76, 658-673. [CrossRef] [PubMed]

82. Bertolacini, C.D.P.; Ribeiro-Bicudo, L.A.; Petrin, A.; Richieri-Costa, A.; Murray, J.C. Clinical findings in patients with GLI2 mutations-Phenotypic variability. Clin. Genet. 2012, 81, 70-75. [CrossRef] [PubMed]

83. Roessler, E.; Du, Y.-Z.; Mullor, J.L.; Casas, E.; Allen, W.P.; Gillessen-Kaesbach, G.; Roeder, E.R.; Ming, J.E.; Ruiz i Altaba, A.; Muenke, M. Loss-of-function mutations in the human GLI2 gene are associated with pituitary anomalies and holoprosencephaly-like features. Proc. Natl. Acad. Sci. USA 2003, 100, 13424-13429. [CrossRef] [PubMed]

84. Kremer Hovinga, I.C.L.; Giltay, J.C.; van der Crabben, S.N.; Steyls, A.; van der Kamp, H.J.; Paulussen, A.D.C. Extreme phenotypic variability of a novel GLI2 mutation in a large family with panhypopituitarism and polydactyly: Clinical implications. Clin. Endocrinol. (Oxf.) 2018. [CrossRef] [PubMed]

85. Rahimov, F.; Ribeiro, L.A.; de Miranda, E.; Richieri-Costa, A.; Murray, J.C. GLI2 mutations in four Brazilian patients: How wide is the phenotypic spectrum? Am. J. Med. Genet. Part A 2006, 140A, 2571-2576. [CrossRef] [PubMed]

86. Gustavsson, P.; Schoumans, J.; Staaf, J.; Jönsson, G.; Carlsson, F.; Kristoffersson, U.; Borg, A.; Nordenskjöld, M.; Dahl, N. Hemizygosity for chromosome 2q14.2-q22.1 spanning the GLI2 and PROC genes associated with growth hormone deficiency, polydactyly, deep vein thrombosis and urogenital abnormalities. Clin. Genet. 2006, 69, 441-443. [CrossRef] [PubMed]

87. Kevelam, S.H.G.; van Harssel, J.J.T.; van der Zwaag, B.; Smeets, H.J.M.; Paulussen, A.D.C.; Lichtenbelt, K.D. A patient with a mild holoprosencephaly spectrum phenotype and heterotaxy and a $1.3 \mathrm{Mb}$ deletion encompassing GLI2. Am. J. Med. Genet. Part A 2011, 158A, 166-173. [CrossRef] [PubMed]

88. Greally, M.T.; Robinson, E.; Allen, N.M.; O’Donovan, D.; Crolla, J.A. De novo interstitial deletion 2q14.1q22.1: Is there a recognizable phenotype? Am. J. Med. Genet. A 2014, 164A, 3194-3202. [CrossRef] [PubMed]

89. Ma, D.; Marion, R.; Punjabi, N.P.; Pereira, E.; Samanich, J.; Agarwal, C.; Li, J.; Huang, C.-K.; Ramesh, K.H.; Cannizzaro, L.A.; et al. A de novo $10.79 \mathrm{Mb}$ interstitial deletion at 2q13q14.2 involving PAX8 causing hypothyroidism and mullerian agenesis: A novel case report and literature review. Mol. Cytogenet. 2014, 7, 85. [CrossRef] [PubMed]

90. Kordaß, U.; Schröder, C.; Elbracht, M.; Soellner, L.; Eggermann, T. A familial GLI2 deletion (2q14.2) not associated with the holoprosencephaly syndrome phenotype. Am. J. Med. Genet. A 2015, 167A, 1121-1124. [CrossRef] [PubMed]

91. Goumy, C.; Gay-Bellile, M.; Salaun, G.; Kemeny, S.; Eymard-Pierre, E.; Biard, M.; Pebrel-Richard, C.; Vanlieferinghen, P.; Francannet, C.; Tchirkov, A.; et al. A novel 2q14.1q14.3 deletion involving GLI2 and RNU4ATAC genes associated with partial corpus callosum agenesis and severe intrauterine growth retardation. Birth Defects Res. Part A Clin. Mol. Teratol. 2016, 106, 793-797. [CrossRef] [PubMed] 
92. Niida, Y.; Inoue, M.; Ozaki, M.; Takase, E. Human Malformation Syndromes of Defective GLI: Opposite Phenotypes of 2q14.2 (GLI2) and 7p14.2 (GLI3) Microdeletions and a GLIA/R Balance Model. Cytogenet. Genome Res. 2017, 153, 56-65. [CrossRef] [PubMed]

93. Biesecker, L.G. The Greig cephalopolysyndactyly syndrome. Orphanet J. Rare Dis. 2008, 3, 10. [CrossRef] [PubMed]

94. Volodarsky, M.; Langer, Y.; Birk, O.S. A novel GLI3 mutation affecting the zinc finger domain leads to preaxial-postaxial polydactyly-syndactyly complex. BMC Med. Genet. 2014, 15, 110. [CrossRef] [PubMed]

95. Speksnijder, L.; Cohen-Overbeek, T.E.; Knapen, M.F.C.M.; Lunshof, S.M.; Hoogeboom, A.J.M.; van den Ouwenland, A.M.; de Coo, I.F.M.; Lequin, M.H.; Bolz, H.J.; Bergmann, C.; et al. A de novo GLI3 mutation in a patient with acrocallosal syndrome. Am. J. Med. Genet. A 2013, 161A, 1394-1400. [CrossRef] [PubMed]

96. Al-Qattan, M.M.; Shamseldin, H.E.; Salih, M.A.; Alkuraya, F.S. GLI3-related polydactyly: A review. Clin. Genet. 2017, 92, 457-466. [CrossRef] [PubMed]

97. Biesecker, L.G. Pallister-Hall Syndrome. In GeneReviews ${ }^{\circledR}$; Adam, M.P., Ardinger, H.H., Pagon, R.A., Wallace, S.E., Bean, L.J., Stephens, K., Amemiya, A., Eds.; University of Washington: Seattle, WA, USA, 1993.

98. Huang, S.Y.; Yang, J.-Y. Targeting the Hedgehog Pathway in Pediatric Medulloblastoma. Cancers (Basel) 2015, 7, 2110-2123. [CrossRef] [PubMed]

99. Fecher, L.A.; Sharfman, W.H. Advanced basal cell carcinoma, the hedgehog pathway, and treatment options-Role of smoothened inhibitors. Biologics 2015, 9, 129-140. [CrossRef] [PubMed]

100. Liu, C.; Li, D.; Jiang, J.; Hu, J.; Zhang, W.; Chen, Y.; Cui, X.; Qi, Y.; Zou, H.; Zhang, W.; et al. Analysis of molecular cytogenetic alteration in rhabdomyosarcoma by array comparative genomic hybridization. PLoS ONE 2014, 9, e94924. [CrossRef] [PubMed]

101. Duman-Scheel, M.; Weng, L.; Xin, S.; Du, W. Hedgehog regulates cell growth and proliferation by inducing Cyclin D and Cyclin E. Nature 2002, 417, 299-304. [CrossRef] [PubMed]

102. Bigelow, R.L.H. Transcriptional Regulation of bcl-2 Mediated by the Sonic Hedgehog Signaling Pathway through gli-1. J. Biol. Chem. 2003, 279, 1197-1205. [CrossRef] [PubMed]

103. Pola, R.; Ling, L.E.; Silver, M.; Corbley, M.J.; Kearney, M.; Blake Pepinsky, R.; Shapiro, R.; Taylor, F.R.; Baker, D.P.; Asahara, T.; et al. The morphogen Sonic hedgehog is an indirect angiogenic agent upregulating two families of angiogenic growth factors. Nat. Med. 2001, 7, 706-711. [CrossRef] [PubMed]

104. Talbot, L.J.; Bhattacharya, S.D.; Kuo, P.C. Epithelial-mesenchymal transition, the tumor microenvironment, and metastatic behavior of epithelial malignancies. Int. J. Biochem. Mol. Biol. 2012, 3, 117-136. [PubMed]

105. Bora-Singhal, N.; Perumal, D.; Nguyen, J.; Chellappan, S. Gli1-Mediated Regulation of Sox2 Facilitates Self-Renewal of Stem-Like Cells and Confers Resistance to EGFR Inhibitors in Non-Small Cell Lung Cancer. Neoplasia 2015, 17, 538-551. [CrossRef] [PubMed]

106. Brandner, S. Nanog, Gli, and p53: A new network of stemness in development and cancer. EMBO J. 2010, 29, 2475-2476. [CrossRef] [PubMed]

107. Scales, S.J.; de Sauvage, F.J. Mechanisms of Hedgehog pathway activation in cancer and implications for therapy. Trends Pharmacol. Sci. 2009, 30, 303-312. [CrossRef] [PubMed]

108. Kar, S.; Deb, M.; Sengupta, D.; Shilpi, A.; Bhutia, S.K.; Patra, S.K. Intricacies of hedgehog signaling pathways: A perspective in tumorigenesis. Exp. Cell Res. 2012, 318, 1959-1972. [CrossRef] [PubMed]

109. Teglund, S.; Toftgård, R. Hedgehog beyond medulloblastoma and basal cell carcinoma. Biochim. Biophys. Acta (BBA) Rev. Cancer 2010, 1805, 181-208. [CrossRef] [PubMed]

110. Berman, D.M.; Karhadkar, S.S.; Maitra, A.; Montes De Oca, R.; Gerstenblith, M.R.; Briggs, K.; Parker, A.R.; Shimada, Y.; Eshleman, J.R.; Watkins, D.N.; et al. Widespread requirement for Hedgehog ligand stimulation in growth of digestive tract tumours. Nature 2003, 425, 846-851. [CrossRef] [PubMed]

111. Thayer, S.P.; di Magliano, M.P.; Heiser, P.W.; Nielsen, C.M.; Roberts, D.J.; Lauwers, G.Y.; Qi, Y.P.; Gysin, S.; Fernández-del Castillo, C.; Yajnik, V.; et al. Hedgehog is an early and late mediator of pancreatic cancer tumorigenesis. Nature 2003, 425, 851-856. [CrossRef] [PubMed]

112. Watkins, D.N.; Berman, D.M.; Burkholder, S.G.; Wang, B.; Beachy, P.A.; Baylin, S.B. Hedgehog signalling within airway epithelial progenitors and in small-cell lung cancer. Nature 2003, 422, 313-317. [CrossRef] [PubMed]

113. Yuan, Z.; Goetz, J.A.; Singh, S.; Ogden, S.K.; Petty, W.J.; Black, C.C.; Memoli, V.A.; Dmitrovsky, E.; Robbins, D.J. Frequent requirement of hedgehog signaling in non-small cell lung carcinoma. Oncogene 2006, 26, 1046-1055. [CrossRef] [PubMed] 
114. Qualtrough, D.; Buda, A.; Gaffield, W.; Williams, A.C.; Paraskeva, C. Hedgehog signalling in colorectal tumour cells: Induction of apoptosis with cyclopamine treatment. Int. J. Cancer 2004, 110, 831-837. [CrossRef] [PubMed]

115. Karhadkar, S.S.; Bova, G.S.; Abdallah, N.; Dhara, S.; Gardner, D.; Maitra, A.; Isaacs, J.T.; Berman, D.M.; Beachy, P.A. Hedgehog signalling in prostate regeneration, neoplasia and metastasis. Nature 2004, 431, 707-712. [CrossRef] [PubMed]

116. Sanchez, P.; Hernández, A.M.; Stecca, B.; Kahler, A.J.; DeGueme, A.M.; Barrett, A.; Beyna, M.; Datta, M.W.; Datta, S.; Ruiz i Altaba, A. Inhibition of prostate cancer proliferation by interference with SONIC HEDGEHOG-GLI1 signaling. Proc. Natl. Acad. Sci. USA 2004, 101, 12561-12566. [CrossRef] [PubMed]

117. Mukherjee, S.; Frolova, N.; Sadlonova, A.; Novak, Z.; Steg, A.; Page, G.; Welch, D.R.; Lobo-Ruppert, S.M.; Ruppert, J.M.; Johnson, M.R.; et al. Hedgehog signaling and response to cyclopamine differs in epithelial and stromal cells in benign breast and breast cancer. Cancer Biol. Ther. 2006, 5, 674-683. [CrossRef] [PubMed]

118. Stecca, B.; Mas, C.; Clement, V.; Zbinden, M.; Correa, R.; Piguet, V.; Beermann, F.; Ruiz i Altaba, A. Melanomas require HEDGEHOG-GLI signaling regulated by interactions between GLI1 and the RAS-MEK/AKT pathways. Proc. Natl. Acad. Sci. USA 2007, 104, 5895-5900. [CrossRef] [PubMed]

119. Ma, X.; Sheng, T.; Zhang, Y.; Zhang, X.; He, J.; Huang, S.; Chen, K.; Sultz, J.; Adegboyega, P.A.; Zhang, H.; et al. Hedgehog signaling is activated in subsets of esophageal cancers. Int. J. Cancer 2006, 118, 139-148. [CrossRef] [PubMed]

120. Fan, L.; Pepicelli, C.V.; Dibble, C.C.; Catbagan, W.; Zarycki, J.L.; Laciak, R.; Gipp, J.; Shaw, A.; Lamm, M.L.G.; Munoz, A.; et al. Hedgehog signaling promotes prostate xenograft tumor growth. Endocrinology 2004, 145, 3961-3970. [CrossRef] [PubMed]

121. Yauch, R.L.; Gould, S.E.; Scales, S.J.; Tang, T.; Tian, H.; Ahn, C.P.; Marshall, D.; Fu, L.; Januario, T.; Kallop, D.; et al. A paracrine requirement for hedgehog signalling in cancer. Nature 2008, 455, 406-410. [CrossRef] [PubMed]

122. Santini, R.; Vinci, M.C.; Pandolfi, S.; Penachioni, J.Y.; Montagnani, V.; Olivito, B.; Gattai, R.; Pimpinelli, N.; Gerlini, G.; Borgognoni, L.; et al. HEDGEHOG-GLI Signaling Drives Self-Renewal and Tumorigenicity of Human Melanoma-Initiating Cells. Stem Cells 2012, 30, 1808-1818. [CrossRef] [PubMed]

123. Varnat, F.; Duquet, A.; Malerba, M.; Zbinden, M.; Mas, C.; Gervaz, P.; Ruiz i Altaba, A. Human colon cancer epithelial cells harbour active HEDGEHOG-GLI signalling that is essential for tumour growth, recurrence, metastasis and stem cell survival and expansion. EMBO Mol. Med. 2009, 1, 338-351. [CrossRef] [PubMed]

124. Whisenant, T.C.; Ho, D.T.; Benz, R.W.; Rogers, J.S.; Kaake, R.M.; Gordon, E.A.; Huang, L.; Baldi, P.; Bardwell, L. Computational Prediction and Experimental Verification of New MAP Kinase Docking Sites and Substrates Including Gli Transcription Factors. PLoS Comput. Biol. 2010, 6, e1000908. [CrossRef] [PubMed]

125. Ji, Z.; Mei, F.C.; Xie, J.; Cheng, X. Oncogenic KRAS Activates Hedgehog Signaling Pathway in Pancreatic Cancer Cells. J. Biol. Chem. 2007, 282, 14048-14055. [CrossRef] [PubMed]

126. Riobo, N.A.; Lu, K.; Ai, X.; Haines, G.M.; Emerson, C.P. Phosphoinositide 3-kinase and Akt are essential for Sonic Hedgehog signaling. Proc. Natl. Acad. Sci. USA 2006, 103, 4505-4510. [CrossRef] [PubMed]

127. Dennler, S.; André, J.; Alexaki, I.; Li, A.; Magnaldo, T.; ten Dijke, P.; Wang, X.-J.; Verrecchia, F.; Mauviel, A. Induction of sonic hedgehog mediators by transforming growth factor-beta: Smad3-dependent activation of Gli2 and Gli1 expression in vitro and in vivo. Cancer Res. 2007, 67, 6981-6986. [CrossRef] [PubMed]

128. Nolan-Stevaux, O.; Lau, J.; Truitt, M.L.; Chu, G.C.; Hebrok, M.; Fernández-Zapico, M.E.; Hanahan, D. GLI1 is regulated through Smoothened-independent mechanisms in neoplastic pancreatic ducts and mediates PDAC cell survival and transformation. Genes Dev. 2009, 23, 24-36. [CrossRef] [PubMed]

129. Schnidar, H.; Eberl, M.; Klingler, S.; Mangelberger, D.; Kasper, M.; Hauser-Kronberger, C.; Regl, G.; Kroismayr, R.; Moriggl, R.; Sibilia, M.; et al. Epidermal growth factor receptor signaling synergizes with Hedgehog/GLI in oncogenic transformation via activation of the MEK/ERK/JUN pathway. Cancer Res. 2009, 69, 1284-1292. [CrossRef] [PubMed]

130. Atwood, S.X.; Li, M.; Lee, A.; Tang, J.Y.; Oro, A.E. GLI activation by atypical protein kinase $C \iota / \lambda$ regulates the growth of basal cell carcinomas. Nature 2013, 494, 484-488. [CrossRef] [PubMed]

131. Cai, Q.; Li, J.; Gao, T.; Xie, J.; Evers, B.M. Protein Kinase C $\delta$ Negatively Regulates Hedgehog Signaling by Inhibition of Gli1 Activity. J. Biol. Chem. 2009, 284, 2150-2158. [CrossRef] [PubMed]

132. Wang, Y.; Ding, Q.; Yen, C.-J.; Xia, W.; Izzo, J.G.; Lang, J.-Y.; Li, C.-W.; Hsu, J.L.; Miller, S.A.; Wang, X.; et al. The crosstalk of mTOR/S6K1 and Hedgehog pathways. Cancer Cell 2012, 21, 374-387. [CrossRef] [PubMed] 
133. Wang, Y.; Jin, G.; Li, Q.; Wang, Z.; Hu, W.; Li, P.; Li, S.; Wu, H.; Kong, X.; Gao, J.; et al. Hedgehog Signaling Non-Canonical Activated by Pro-Inflammatory Cytokines in Pancreatic Ductal Adenocarcinoma. J. Cancer 2016, 7, 2067-2076. [CrossRef] [PubMed]

134. Colavito, S.A.; Zou, M.R.; Yan, Q.; Nguyen, D.X.; Stern, D.F. Significance of glioma-associated oncogene homolog 1 (GLI1) expression in claudin-low breast cancer and crosstalk with the nuclear factor kappa-light-chain-enhancer of activated b cells (NF-kB) pathway. Breast Cancer Res. 2014, 16, 444. [CrossRef] [PubMed]

135. Pandolfi, S.; Montagnani, V.; Penachioni, J.Y.; Vinci, M.C.; Olivito, B.; Borgognoni, L.; Stecca, B. WIP1 phosphatase modulates the Hedgehog signaling by enhancing GLI1 function. Oncogene 2013, 32, 4737-4747. [CrossRef] [PubMed]

136. Abe, Y.; Oda-Sato, E.; Tobiume, K.; Kawauchi, K.; Taya, Y.; Okamoto, K.; Oren, M.; Tanaka, N. Hedgehog signaling overrides p53-mediated tumor suppression by activating Mdm2. Proc. Natl. Acad. Sci. USA 2008, 105, 4838-4843. [CrossRef] [PubMed]

137. Gu, D.; Xie, J. Non-Canonical Hh Signaling in Cancer-Current Understanding and Future Directions. Cancers (Basel) 2015, 7, 1684-1698. [CrossRef] [PubMed]

138. Beauchamp, E.; Bulut, G.; Abaan, O.; Chen, K.; Merchant, A.; Matsui, W.; Endo, Y.; Rubin, J.S.; Toretsky, J.; Uren, A. GLI1 is a direct transcriptional target of EWS-FLI1 oncoprotein. J. Biol. Chem. 2009, 284, 9074-9082. [CrossRef] [PubMed]

139. Yoon, J.W.; Gallant, M.; Lamm, M.L.G.; Iannaccone, S.; Vieux, K.-F.; Proytcheva, M.; Hyjek, E.; Iannaccone, P.; Walterhouse, D. Noncanonical regulation of the Hedgehog mediator GLI1 by c-MYC in Burkitt lymphoma. Mol. Cancer Res. 2013, 11, 604-615. [CrossRef] [PubMed]

140. Flora, A.; Klisch, T.J.; Schuster, G.; Zoghbi, H.Y. Deletion of Atoh1 disrupts Sonic Hedgehog signaling in the developing cerebellum and prevents medulloblastoma. Science 2009, 326, 1424-1427. [CrossRef] [PubMed]

141. Inaguma, S.; Kasai, K.; Ikeda, H. GLI1 facilitates the migration and invasion of pancreatic cancer cells through MUC5AC-mediated attenuation of E-cadherin. Oncogene 2011, 30, 714-723. [CrossRef] [PubMed]

142. Trnski, D.; Sabol, M.; Gojević, A.; Martinić, M.; Ozretić, P.; Musani, V.; Ramić, S.; Levanat, S. GSK3 $\beta$ and Gli3 play a role in activation of Hedgehog-Gli pathway in human colon cancer-Targeting GSK3 $\beta$ downregulates the signaling pathway and reduces cell proliferation. Biochim. Biophys. Acta 2015, 1852, 2574-2584. [CrossRef] [PubMed]

143. Shimokawa, T.; Rahman, M.F.-U.; Tostar, U.; Sonkoly, E.; Ståhle, M.; Pivarcsi, A.; Palaniswamy, R.; Zaphiropoulos, P.G. RNA editing of the GLI1 transcription factor modulates the output of Hedgehog signaling. RNA Biol. 2013, 10, 321-333. [CrossRef] [PubMed]

144. Lazzari, E.; Mondala, P.K.; Santos, N.D.; Miller, A.C.; Pineda, G.; Jiang, Q.; Leu, H.; Ali, S.A.; Ganesan, A.-P.; $\mathrm{Wu}, \mathrm{C} . \mathrm{N}$; et al. Alu-dependent RNA editing of GLI1 promotes malignant regeneration in multiple myeloma. Nat. Commun. 2017, 8, 1922. [CrossRef] [PubMed]

145. Kinzler, K.; Bigner, S.; Bigner, D.; Trent, J.; Law, M.; O’Brien, S.; Wong, A.; Vogelstein, B. Identification of an amplified, highly expressed gene in a human glioma. Science 1987, 236, 70-73. [CrossRef] [PubMed]

146. Northcott, P.A.; Nakahara, Y.; Wu, X.; Feuk, L.; Ellison, D.W.; Croul, S.; Mack, S.; Kongkham, P.N.; Peacock, J.; Dubuc, A.; et al. Multiple recurrent genetic events converge on control of histone lysine methylation in medulloblastoma. Nat. Genet. 2009, 41, 465-472. [CrossRef] [PubMed]

147. Naylor, T.L.; Greshock, J.; Wang, Y.; Colligon, T.; Yu, Q.C.; Clemmer, V.; Zaks, T.Z.; Weber, B.L. High resolution genomic analysis of sporadic breast cancer using array-based comparative genomic hybridization. Breast Cancer Res. 2005, 7, R1186-R1198. [CrossRef] [PubMed]

148. Nessling, M.; Richter, K.; Schwaenen, C.; Roerig, P.; Wrobel, G.; Wessendorf, S.; Fritz, B.; Bentz, M.; Sinn, H.-P.; Radlwimmer, B.; et al. Candidate genes in breast cancer revealed by microarray-based comparative genomic hybridization of archived tissue. Cancer Res. 2005, 65, 439-447. [PubMed]

149. Roberts, W.M.; Douglass, E.C.; Peiper, S.C.; Houghton, P.J.; Look, A.T. Amplification of the gli gene in childhood sarcomas. Cancer Res. 1989, 49, 5407-5413. [PubMed]

150. Snijders, A.M.; Schmidt, B.L.; Fridlyand, J.; Dekker, N.; Pinkel, D.; Jordan, R.C.K.; Albertson, D.G. Rare amplicons implicate frequent deregulation of cell fate specification pathways in oral squamous cell carcinoma. Oncogene 2005, 24, 4232-4242. [CrossRef] [PubMed] 
151. Dahlén, A.; Mertens, F.; Mandahl, N.; Panagopoulos, I. Molecular genetic characterization of the genomic ACTB-GLI fusion in pericytoma with $\mathrm{t}(7 ; 12)$. Biochem. Biophys. Res. Commun. 2004, 325, 1318-1323. [CrossRef] [PubMed]

152. Bridge, J.A.; Sanders, K.; Huang, D.; Nelson, M.; Neff, J.R.; Muirhead, D.; Walker, C.; Seemayer, T.A.; Sumegi, J. Pericytoma with t(7;12) and ACTB-GLI1 fusion arising in bone. Hum. Pathol. 2012, 43, 1524-1529. [CrossRef] [PubMed]

153. Kuromi, T.; Matsushita, M.; Iwasaki, T.; Nonaka, D.; Kuwamoto, S.; Nagata, K.; Kato, M.; Akizuki, G.; Kitamura, Y.; Hayashi, K. Association of expression of the hedgehog signal with Merkel cell polyomavirus infection and prognosis of Merkel cell carcinoma. Hum. Pathol. 2017, 69, 8-14. [CrossRef] [PubMed]

154. Dagklis, A.; Pauwels, D.; Lahortiga, I.; Geerdens, E.; Bittoun, E.; Cauwelier, B.; Tousseyn, T.; Uyttebroeck, A.; Maertens, J.; Verhoef, G.; et al. Hedgehog pathway mutations in T-cell acute lymphoblastic leukemia. Haematologica 2015, 100, e102-e105. [CrossRef] [PubMed]

155. Lee, J.H.; Song, S.Y.; Kim, M.S.; Yoo, N.J.; Lee, S.H. Intratumoral Heterogeneity of Frameshift Mutations of GLI1 Encoding a Hedgehog Signaling Protein in Colorectal Cancers. Pathol. Oncol. Res. 2018, 24, 477-481. [CrossRef] [PubMed]

156. Sjöblom, T.; Jones, S.; Wood, L.D.; Parsons, D.W.; Lin, J.; Barber, T.D.; Mandelker, D.; Leary, R.J.; Ptak, J.; Silliman, N.; et al. The consensus coding sequences of human breast and colorectal cancers. Science 2006, 314, 268-274. [CrossRef] [PubMed]

157. Wood, L.D.; Parsons, D.W.; Jones, S.; Lin, J.; Sjöblom, T.; Leary, R.J.; Shen, D.; Boca, S.M.; Barber, T.; Ptak, J.; et al. The genomic landscapes of human breast and colorectal cancers. Science 2007, 318, 1108-1113. [CrossRef] [PubMed]

158. Lucchesi, C.; Khalifa, E.; Laizet, Y.; Soubeyran, I.; Mathoulin-Pelissier, S.; Chomienne, C.; Italiano, A. Targetable Alterations in Adult Patients With Soft-Tissue Sarcomas: Insights for Personalized Therapy. JAMA Oncol. 2018. [CrossRef] [PubMed]

159. Jones, S.; Zhang, X.; Parsons, D.W.; Lin, J.C.-H.; Leary, R.J.; Angenendt, P.; Mankoo, P.; Carter, H.; Kamiyama, H.; Jimeno, A.; et al. Core Signaling Pathways in Human Pancreatic Cancers Revealed by Global Genomic Analyses. Science 2008, 321, 1801-1806. [CrossRef] [PubMed]

160. Forbes, S.A.; Beare, D.; Boutselakis, H.; Bamford, S.; Bindal, N.; Tate, J.; Cole, C.G.; Ward, S.; Dawson, E.; Ponting, L.; et al. COSMIC: Somatic cancer genetics at high-resolution. Nucleic Acids Res. 2017, 45, D777-D783. [CrossRef] [PubMed]

161. Huntzicker, E.G.; Estay, I.S.; Zhen, H.; Lokteva, L.A.; Jackson, P.K.; Oro, A.E. Dual degradation signals control Gli protein stability and tumor formation. Genes Dev. 2006, 20, 276-281. [CrossRef] [PubMed]

162. Song, Y.; Zuo, Y. Occurrence of HHIP gene CpG island methylation in gastric cancer. Oncol. Lett. 2014, 8, 2340-2344. [CrossRef] [PubMed]

163. Cretnik, M.; Musani, V.; Oreskovic, S.; Leovic, D.; Levanat, S. The Patched gene is epigenetically regulated in ovarian dermoids and fibromas, but not in basocellular carcinomas. Int. J. Mol. Med. 2007, 19, 875-883. [CrossRef] [PubMed]

164. Löf-Öhlin, Z.M.; Levanat, S.; Sabol, M.; Sorbe, B.; Nilsson, T.K. Promoter methylation in the PTCH gene in cervical epithelial cancer and ovarian cancer tissue as studied by eight novel Pyrosequencing ${ }^{\circledR}$ assays. Int. J. Oncol. 2011, 38, 685-692. [CrossRef] [PubMed]

165. Zhao, J.; Quan, H.; Xie, C.; Lou, L. NL-103, a novel dual-targeted inhibitor of histone deacetylases and hedgehog pathway, effectively overcomes vismodegib resistance conferred by Smo mutations. Pharmacol. Res. Perspect. 2014, 2, e00043. [CrossRef] [PubMed]

166. Levanat, S.; Sabol, M.; Musani, V.; Ozretic, P.; Trnski, D. Hedgehog signaling pathway as genetic and epigenetic target in ovarian tumors. Curr. Pharm. Des. 2017, 23, 73-94. [CrossRef] [PubMed]

167. Biswas, S.; Rao, C.M. Epigenetics in cancer: Fundamentals and Beyond. Pharmacol. Ther. 2017, 173, 118-134. [CrossRef] [PubMed]

168. Loh, M.; Liem, N.; Vaithilingam, A.; Lim, P.L.; Sapari, N.S.; Elahi, E.; Mok, Z.Y.; Cheng, C.L.; Yan, B.; Pang, B.; et al. DNA methylation subgroups and the CpG island methylator phenotype in gastric cancer: A comprehensive profiling approach. BMC Gastroenterol. 2014, 14, 55. [CrossRef] [PubMed]

169. Shahi, M.H.; Lorente, A.; Castresana, J.S. Hedgehog signalling in medulloblastoma, glioblastoma and neuroblastoma. Oncol. Rep. 2008, 19, 681-688. [CrossRef] [PubMed] 
170. Song, Y.; Zhang, J.; Tian, T.; Fu, X.; Wang, W.; Li, S.; Shi, T.; Suo, A.; Ruan, Z.; Guo, H.; et al. SET7/9 inhibits oncogenic activities through regulation of Gli-1 expression in breast cancer. Tumor Biol. 2016, 37, 9311-9322. [CrossRef] [PubMed]

171. Fu, L.; Wu, H.; Cheng, S.Y.; Gao, D.; Zhang, L.; Zhao, Y. Set7 mediated Gli3 methylation plays a positive role in the activation of Sonic Hedgehog pathway in mammals. Elife 2016, 5, e15690. [CrossRef] [PubMed]

172. Villegas, V.E.; Rahman, M.F.-U.; Fernandez-Barrena, M.G.; Diao, Y.; Liapi, E.; Sonkoly, E.; Ståhle, M.; Pivarcsi, A.; Annaratone, L.; Sapino, A.; et al. Identification of novel non-coding RNA-based negative feedback regulating the expression of the oncogenic transcription factor GLI1. Mol. Oncol. 2014, 8, 912-926. [CrossRef] [PubMed]

173. Ferretti, E.; De Smaele, E.; Miele, E.; Laneve, P.; Po, A.; Pelloni, M.; Paganelli, A.; Di Marcotullio, L.; Caffarelli, E.; Screpanti, I.; et al. Concerted microRNA control of Hedgehog signalling in cerebellar neuronal progenitor and tumour cells. EMBO J. 2008, 27, 2616-2627. [CrossRef] [PubMed]

174. Ferretti, E.; Smaele, E.D.; Po, A.; Marcotullio, L.D.; Tosi, E.; Espinola, M.S.B.; Rocco, C.D.; Riccardi, R.; Giangaspero, F.; Farcomeni, A.; et al. MicroRNA profiling in human medulloblastoma. Int. J. Cancer 2009, 124, 568-577. [CrossRef] [PubMed]

175. Venkataraman, S.; Birks, D.K.; Balakrishnan, I.; Alimova, I.; Harris, P.S.; Patel, P.R.; Handler, M.H.; Dubuc, A.; Taylor, M.D.; Foreman, N.K.; et al. MicroRNA 218 Acts as a Tumor Suppressor by Targeting Multiple Cancer Phenotype-associated Genes in Medulloblastoma. J. Biol. Chem. 2013, 288, 1918-1928. [CrossRef] [PubMed]

176. Peng, B.; Li, D.; Qin, M.; Luo, D.; Zhang, X.; Zhao, H.; Hu, S. MicroRNA218 inhibits glioma migration and invasion via inhibiting glioma-associated oncogene homolog 1 expression at $\mathrm{N}$ terminus. Tumor Biol. 2014, 35, 3831-3837. [CrossRef] [PubMed]

177. Zhao, Y.; Li, C.; Wang, M.; Su, L.; Qu, Y.; Li, J.; Yu, B.; Yan, M.; Yu, Y.; Liu, B.; et al. Decrease of miR-202-3p Expression, a Novel Tumor Suppressor, in Gastric Cancer. PLoS ONE 2013, 8, e69756. [CrossRef] [PubMed]

178. Zhao, Y.; Huang, J.; Zhang, L.; Qu, Y.; Li, J.; Yu, B.; Yan, M.; Yu, Y.; Liu, B.; Zhu, Z. MiR-133b is frequently decreased in gastric cancer and its overexpression reduces the metastatic potential of gastric cancer cells. BMC Cancer 2014, 14, 34. [CrossRef] [PubMed]

179. Sand, M.; Skrygan, M.; Sand, D.; Georgas, D.; Hahn, S.A.; Gambichler, T.; Altmeyer, P.; Bechara, F.G. Expression of microRNAs in basal cell carcinoma. Br. J. Dermatol. 2012, 167, 847-855. [CrossRef] [PubMed]

180. Ruan, Q.; Fang, Z.; Cui, S.; Zhang, X.; Wu, Y.; Tang, H.; Tu, Y.; Ding, Y. Thermo-chemotherapy Induced miR-218 upregulation inhibits the invasion of gastric cancer via targeting Gli2 and E-cadherin. Tumor Biol. 2015, 36, 5807-5814. [CrossRef] [PubMed]

181. Constantin, L.; Wainwright, B.J. MicroRNAs Promote Granule Cell Expansion in the Cerebellum Through Gli2. Cerebellum 2015, 14, 688-698. [CrossRef] [PubMed]

182. Li, K.K.-W.; Xia, T.; Ma, F.M.T.; Zhang, R.; Mao, Y.; Wang, Y.; Zhou, L.; Lau, K.-M.; Ng, H.-K. miR-106b is overexpressed in medulloblastomas and interacts directly with PTEN. Neuropathol. Appl. Neurobiol. 2015, 41, 145-164. [CrossRef] [PubMed]

183. Jiang, Z.; Cushing, L.; Ai, X.; Lü, J. miR-326 Is Downstream of Sonic Hedgehog Signaling and Regulates the Expression of Gli2 and Smoothened. Am. J. Respir. Cell Mol. Biol. 2014, 51, 273-283. [CrossRef] [PubMed]

184. Yu, F.; Yu, F.; Zheng, Y.; Zheng, Y.; Hong, W.; Hong, W.; Chen, B.; Chen, B.; Dong, P.; Dong, P.; et al. MicroRNA-200a suppresses epithelial-to-mesenchymal transition in rat hepatic stellate cells via GLI family zinc finger 2. Mol. Med. Rep. 2015, 12, 8121-8128. [CrossRef] [PubMed]

185. Feng, J.; Wang, J.; Chen, M.; Chen, G.; Wu, Z.; Ying, L.; Zhuo, Q.; Zhang, J.; Wang, W. miR-200a suppresses cell growth and migration by targeting MACC1 and predicts prognosis in hepatocellular carcinoma. Oncol. Rep. 2015, 33, 713-720. [CrossRef] [PubMed]

186. Hyun, J.; Wang, S.; Kim, J.; Rao, K.M.; Park, S.Y.; Chung, I.; Ha, C.-S.; Kim, S.-W.; Yun, Y.H.; Jung, Y. MicroRNA-378 limits activation of hepatic stellate cells and liver fibrosis by suppressing Gli3 expression. Nat. Commun. 2016, 7, 10993. [CrossRef] [PubMed]

187. Zhang, Y.; Chen, Z.; Li, M.-J.; Guo, H.-Y.; Jing, N.-C. Long non-coding RNA metastasis-associated lung adenocarcinoma transcript 1 regulates the expression of Gli2 by miR-202 to strengthen gastric cancer progression. Biomed. Pharmacother. 2017, 85, 264-271. [CrossRef] [PubMed]

188. Incardona, J.P.; Gaffield, W.; Kapur, R.P.; Roelink, H. The teratogenic Veratrum alkaloid cyclopamine inhibits sonic hedgehog signal transduction. Development 1998, 125, 3553-3562. [PubMed] 
189. Lee, S.T.; Welch, K.D.; Panter, K.E.; Gardner, D.R.; Garrossian, M.; Chang, C.-W.T. Cyclopamine: From Cyclops Lambs to Cancer Treatment. J. Agric. Food Chem. 2014, 62, 7355-7362. [CrossRef] [PubMed]

190. Basset-Séguin, N.; Hauschild, A.; Kunstfeld, R.; Grob, J.; Dréno, B.; Mortier, L.; Ascierto, P.A.; Licitra, L.; Dutriaux, C.; Thomas, L.; et al. Vismodegib in patients with advanced basal cell carcinoma: Primary analysis of STEVIE, an international, open-label trial. Eur. J. Cancer 2017, 86, 334-348. [CrossRef] [PubMed]

191. De Smaele, E.; Ferretti, E.; Gulino, A. Vismodegib, a small-molecule inhibitor of the hedgehog pathway for the treatment of advanced cancers. Curr. Opin. Investig. Drugs 2010, 11, 707-718. [PubMed]

192. Casey, D.; Demko, S.; Shord, S.; Zhao, H.; Chen, H.; He, K.; Putman, A.; Helms, W.; Keegan, P.; Pazdur, R. FDA Approval Summary: Sonidegib for Locally Advanced Basal Cell Carcinoma. Clin. Cancer Res. 2017, 23, 2377-2381. [CrossRef] [PubMed]

193. Sasaki, K.; Gotlib, J.R.; Mesa, R.A.; Newberry, K.J.; Ravandi, F.; Cortes, J.E.; Kelly, P.; Kutok, J.L.; Kantarjian, H.M.; Verstovsek, S. Phase II Evaluation of IPI-926, an Oral Hedgehog Inhibitor, in Patients with Myelofibrosis. Leuk. Lymphoma 2015, 56, 2092-2097. [CrossRef] [PubMed]

194. Jimeno, A.; Weiss, G.J.; Miller, W.H.; Gettinger, S.; Eigl, B.J.C.; Chang, A.L.S.; Dunbar, J.; Devens, S.; Faia, K.; Skliris, G.; et al. Phase I study of the Hedgehog pathway inhibitor IPI-926 in adult patients with solid tumors. Clin. Cancer Res. 2013, 19, 2766-2774. [CrossRef] [PubMed]

195. LoRusso, P.M.; Rudin, C.M.; Reddy, J.C.; Tibes, R.; Weiss, G.J.; Borad, M.J.; Hann, C.L.; Brahmer, J.R.; Chang, I.; Darbonne, W.C.; et al. Phase I Trial of Hedgehog Pathway Inhibitor Vismodegib (GDC-0449) in Patients with Refractory, Locally Advanced or Metastatic Solid Tumors. Clin. Cancer Res. 2011, 17, 2502-2511. [CrossRef] [PubMed]

196. Rodon, J.; Tawbi, H.A.; Thomas, A.L.; Stoller, R.G.; Turtschi, C.P.; Baselga, J.; Sarantopoulos, J.; Mahalingam, D.; Shou, Y.; Moles, M.A.; et al. A Phase I, Multicenter, Open-Label, First-in-Human, Dose-Escalation Study of the Oral Smoothened Inhibitor Sonidegib (LDE225) in Patients with Advanced Solid Tumors. Clin. Cancer Res. 2014, 20, 1900-1909. [CrossRef] [PubMed]

197. Kim, D.J.; Kim, J.; Spaunhurst, K.; Montoya, J.; Khodosh, R.; Chandra, K.; Fu, T.; Gilliam, A.; Molgo, M.; Beachy, P.A.; et al. Open-label, exploratory phase II trial of oral itraconazole for the treatment of basal cell carcinoma. J. Clin. Oncol. 2014, 32, 745-751. [CrossRef] [PubMed]

198. Gonnissen, A.; Isebaert, S.; Haustermans, K. Targeting the Hedgehog signaling pathway in cancer: Beyond Smoothened. Oncotarget 2015, 6, 13899-13913. [CrossRef] [PubMed]

199. Lauth, M.; Bergström, A.; Shimokawa, T.; Toftgård, R. Inhibition of GLI-mediated transcription and tumor cell growth by small-molecule antagonists. Proc. Natl. Acad. Sci. USA 2007, 104, 8455-8460. [CrossRef] [PubMed]

200. Agyeman, A.; Jha, B.K.; Mazumdar, T.; Houghton, J.A. Mode and specificity of binding of the small molecule GANT61 to GLI determines inhibition of GLI-DNA binding. Oncotarget 2014, 5, 4492. [CrossRef] [PubMed]

201. Wickström, M.; Dyberg, C.; Shimokawa, T.; Milosevic, J.; Baryawno, N.; Fuskevåg, O.M.; Larsson, R.; Kogner, P.; Zaphiropoulos, P.G.; Johnsen, J.I. Targeting the hedgehog signal transduction pathway at the level of GLI inhibits neuroblastoma cell growth in vitro and in vivo. Int. J. Cancer 2013, 132, 1516-1524. [CrossRef] [PubMed]

202. Mazumdar, T.; DeVecchio, J.; Agyeman, A.; Shi, T.; Houghton, J.A. Blocking Hedgehog survival signaling at the level of the GLI genes induces DNA damage and extensive cell death in human colon carcinoma cells. Cancer Res. 2011, 71, 5904-5914. [CrossRef] [PubMed]

203. Lim, C.B.; Prêle, C.M.; Baltic, S.; Arthur, P.G.; Creaney, J.; Watkins, D.N.; Thompson, P.J.; Mutsaers, S.E. Mitochondria-derived reactive oxygen species drive GANT61-induced mesothelioma cell apoptosis. Oncotarget 2015, 6, 1519-1530. [CrossRef] [PubMed]

204. Fu, J.; Rodova, M.; Roy, S.K.; Sharma, J.; Singh, K.P.; Srivastava, R.K.; Shankar, S. GANT-61 inhibits pancreatic cancer stem cell growth in vitro and in NOD/SCID/IL2R gamma null mice xenograft. Cancer Lett. 2013, 330, 22-32. [CrossRef] [PubMed]

205. Xu, Y.; Xu, Y.; An, Y.; An, Y.; Wang, X.; Wang, X.; Zha, W.; Zha, W.; Li, X.; Li, X. Inhibition of the Hedgehog pathway induces autophagy in pancreatic ductal adenocarcinoma cells. Oncol. Rep. 2014, 31, 707-712. [CrossRef] [PubMed]

206. Mazumdar, T.; Sandhu, R.; Qadan, M.; DeVecchio, J.; Magloire, V.; Agyeman, A.; Li, B.; Houghton, J.A. Hedgehog Signaling Regulates Telomerase Reverse Transcriptase in Human Cancer Cells. PLoS ONE 2013, 8, e75253. [CrossRef] [PubMed] 
207. Benvenuto, M.; Masuelli, L.; De Smaele, E.; Fantini, M.; Mattera, R.; Cucchi, D.; Bonanno, E.; Di Stefano, E.; Frajese, G.V.; Orlandi, A.; et al. In vitro and in vivo inhibition of breast cancer cell growth by targeting the Hedgehog/GLI pathway with SMO (GDC-0449) or GLI (GANT-61) inhibitors. Oncotarget 2016, 7, 9250-9270. [CrossRef] [PubMed]

208. Arnhold, V.; Boos, J.; Lanvers-Kaminsky, C. Targeting hedgehog signaling pathway in pediatric tumors: In vitro evaluation of SMO and GLI inhibitors. Cancer Chemother. Pharmacol. 2016, 77, 495-505. [CrossRef] [PubMed]

209. Moshai, E.F.; Wémeau-Stervinou, L.; Cigna, N.; Brayer, S.; Sommé, J.M.; Crestani, B.; Mailleux, A.A. Targeting the Hedgehog-Glioma-Associated Oncogene Homolog Pathway Inhibits Bleomycin-Induced Lung Fibrosis in Mice. Am. J. Respir. Cell Mol. Biol. 2014, 51, 11-25. [CrossRef] [PubMed]

210. Huang, L.; Walter, V.; Hayes, D.N.; Onaitis, M. HEDGEHOG-GLI signaling inhibition suppresses tumor growth in squamous lung cancer. Clin. Cancer Res. 2014, 20, 1566-1575. [CrossRef] [PubMed]

211. Tostar, U.; Toftgård, R.; Zaphiropoulos, P.G.; Shimokawa, T. Reduction of Human Embryonal Rhabdomyosarcoma Tumor Growth by Inhibition of the Hedgehog Signaling Pathway. Genes Cancer 2010, 1, 941-951. [CrossRef] [PubMed]

212. Kiesslich, T.; Mayr, C.; Wachter, J.; Bach, D.; Fuereder, J.; Wagner, A.; Alinger, B.; Pichler, M.; Fazio, P.D.; Ocker, M.; et al. Activated hedgehog pathway is a potential target for pharmacological intervention in biliary tract cancer. Mol. Cell. Biochem. 2014, 396, 257-268. [CrossRef] [PubMed]

213. Desch, P.; Asslaber, D.; Kern, D.; Schnidar, H.; Mangelberger, D.; Alinger, B.; Stoecher, M.; Hofbauer, S.W.; Neureiter, D.; Tinhofer, I.; et al. Inhibition of GLI, but not Smoothened, induces apoptosis in chronic lymphocytic leukemia cells. Oncogene 2010, 29, 4885. [CrossRef] [PubMed]

214. Tong, W.; Qiu, L.; Qi, M.; Liu, J.; Hu, K.; Lin, W.; Huang, Y.; Fu, J. GANT-61 and GDC-0449 induce apoptosis of prostate cancer stem cells through a GLI-dependent mechanism. J. Cell. Biochem. 2018, 119, 3641-3652. [CrossRef] [PubMed]

215. Long, B.; Wang, L.-X.; Zheng, F.-M.; Lai, S.-P.; Xu, D.-R.; Hu, Y.; Lin, D.-J.; Zhang, X.-Z.; Dong, L.; Long, Z.-J.; et al. Targeting GLI1 Suppresses Cell Growth and Enhances Chemosensitivity in CD34+ Enriched Acute Myeloid Leukemia Progenitor Cells. CPB 2016, 38, 1288-1302. [CrossRef] [PubMed]

216. Hou, X.; Chen, X.; Zhang, P.; Fan, Y.; Ma, A.; Pang, T.; Song, Z.; Jin, Y.; Hao, W.; Liu, F.; et al. Inhibition of hedgehog signaling by GANT58 induces apoptosis and shows synergistic antitumor activity with AKT inhibitor in acute T cell leukemia cells. Biochimie 2014, 101, 50-59. [CrossRef] [PubMed]

217. Ishiwata, T.; Iwasawa, S.; Ebata, T.; Fan, M.; Tada, Y.; Tatsumi, K.; Takiguchi, Y. Inhibition of Gli leads to antitumor growth and enhancement of cisplatin-induced cytotoxicity in large cell neuroendocrine carcinoma of the lung. Oncol. Rep. 2018, 39, 1148-1154. [CrossRef] [PubMed]

218. Yang, H.; Hu, L.; Liu, Z.; Qin, Y.; Li, R.; Zhang, G.; Zhao, B.; Bi, C.; Lei, Y.; Bai, Y. Inhibition of Gli1-mediated prostate cancer cell proliferation by inhibiting the mTOR/S6K1 signaling pathway. Oncol. Lett. 2017, 14, 7970-7976. [CrossRef] [PubMed]

219. Wellbrock, J.; Latuske, E.; Köhler, J.; Wagner, K.; Stamm, H.; Vettorazzi, E.; Vohwinkel, G.; Klokow, M.; Uibeleisen, R.; Ehm, P.; et al. Expression of Hedgehog Pathway Mediator GLI Represents a Negative Prognostic Marker in Human Acute Myeloid Leukemia and Its Inhibition Exerts Antileukemic Effects. Clin. Cancer Res. 2015, 21, 2388-2398. [CrossRef] [PubMed]

220. Srivastava, R.K.; Kaylani, S.Z.; Edrees, N.; Li, C.; Talwelkar, S.S.; Xu, J.; Palle, K.; Pressey, J.G.; Athar, M. GLI inhibitor GANT-61 diminishes embryonal and alveolar rhabdomyosarcoma growth by inhibiting Shh/AKT-mTOR axis. Oncotarget 2014, 5, 12151-12165. [CrossRef] [PubMed]

221. Wang, J.; Gu, S.; Huang, J.; Chen, S.; Zhang, Z.; Xu, M. Inhibition of autophagy potentiates the efficacy of Gli inhibitor GANT-61 in MYCN-amplified neuroblastoma cells. BMC Cancer 2014, 14, 768. [CrossRef] [PubMed]

222. Matsumoto, T.; Tabata, K.; Suzuki, T. The GANT61, a GLI inhibitor, induces caspase-independent apoptosis of SK-N-LO cells. Biol. Pharm. Bull. 2014, 37, 633-641. [CrossRef] [PubMed]

223. Chen, Q.; Xu, R.; Zeng, C.; Lu, Q.; Huang, D.; Shi, C.; Zhang, W.; Deng, L.; Yan, R.; Rao, H.; et al. Down-regulation of Gli transcription factor leads to the inhibition of migration and invasion of ovarian cancer cells via integrin $\beta 4$-mediated FAK signaling. PLoS ONE 2014, 9, e88386. [CrossRef] [PubMed] 
224. Geng, L.; Lu, K.; Li, P.; Li, X.; Zhou, X.; Li, Y.; Wang, X. GLI1 inhibitor GANT61 exhibits antitumor efficacy in T-cell lymphoma cells through down-regulation of p-STAT3 and SOCS3. Oncotarget 2016, 8, 48701-48710. [CrossRef] [PubMed]

225. Samarzija, I.; Beard, P. Hedgehog pathway regulators influence cervical cancer cell proliferation, survival and migration. Biochem. Biophysical Res. Commun. 2012, 425, 64-69. [CrossRef] [PubMed]

226. Vlčková, K.; Réda, J.; Ondrušová, L.; Krayem, M.; Ghanem, G.; Vachtenheim, J. GLI inhibitor GANT61 kills melanoma cells and acts in synergy with obatoclax. Int. J. Oncol. 2016, 49, 953-960. [CrossRef] [PubMed]

227. Han, J.; Sang, F.; Chang, J.; Hua, Y.; Shi, W.; Tang, L.; Liu, L. Arsenic trioxide inhibits viability of pancreatic cancer stem cells in culture and in a xenograft model via binding to SHH-Gli. Onco Targets Ther. 2013, 6, 1129-1138. [CrossRef] [PubMed]

228. Kim, J.; Lee, J.J.; Kim, J.; Gardner, D.; Beachy, P.A. Arsenic antagonizes the Hedgehog pathway by preventing ciliary accumulation and reducing stability of the Gli2 transcriptional effector. Proc. Natl. Acad. Sci. USA 2010, 107, 13432-13437. [CrossRef] [PubMed]

229. Beauchamp, E.M.; Ringer, L.; Bulut, G.; Sajwan, K.P.; Hall, M.D.; Lee, Y.-C.; Peaceman, D.; Özdemirli, M.; Rodriguez, O.; Macdonald, T.J.; et al. Arsenic trioxide inhibits human cancer cell growth and tumor development in mice by blocking Hedgehog/GLI pathway. J. Clin. Investig. 2011, 121, 148-160. [CrossRef] [PubMed]

230. Nakamura, S.; Nagano, S.; Nagao, H.; Ishidou, Y.; Yokouchi, M.; Abematsu, M.; Yamamoto, T.; Komiya, S.; Setoguchi, T. Arsenic Trioxide Prevents Osteosarcoma Growth by Inhibition of GLI Transcription via DNA Damage Accumulation. PLoS ONE 2013, 8, e69466. [CrossRef] [PubMed]

231. Saitoh, Y.; Setoguchi, T.; Nagata, M.; Tsuru, A.; Nakamura, S.; Nagano, S.; Ishidou, Y.; Nagao-Kitamoto, H.; Yokouchi, M.; Maeda, S.; et al. Combination of Hedgehog inhibitors and standard anticancer agents synergistically prevent osteosarcoma growth. Int. J. Oncol. 2016, 48, 235-242. [CrossRef] [PubMed]

232. Xiong, Y.J.; Guo, Y.J.; Gao, Y.R.; Li, S.; Dai, Z.H.; Dong, X.Q.; Xu, Y.F.; Liu, C.Q.; Liu, Z.Y. Synergism between arsenic trioxide and cyclopamine in the inhibition of PC3 cell survival via the Hedgehog signaling pathway. Neoplasma 2015, 62, 894-904. [CrossRef] [PubMed]

233. Kerl, K.; Moreno, N.; Holsten, T.; Ahlfeld, J.; Mertins, J.; Hotfilder, M.; Kool, M.; Bartelheim, K.; Schleicher, S.; Handgretinger, R.; et al. Arsenic trioxide inhibits tumor cell growth in malignant rhabdoid tumors in vitro and in vivo by targeting overexpressed Gli1. Int. J. Cancer 2014, 135, 989-995. [CrossRef] [PubMed]

234. Li, X.-Y.; Zhou, L.-F.; Gao, L.-J.; Wei, Y.; Xu, S.-F.; Chen, F.-Y.; Huang, W.-J.; Tan, W.-F.; Ye, Y.-P. Cynanbungeigenin $\mathrm{C}$ and $\mathrm{D}$, a pair of novel epimers from Cynanchum bungei, suppress hedgehog pathway-dependent medulloblastoma by blocking signaling at the level of Gli. Cancer Lett. 2018, 420, 195-207. [CrossRef] [PubMed]

235. Subramani, R.; Gonzalez, E.; Nandy, S.B.; Arumugam, A.; Camacho, F.; Medel, J.; Alabi, D.; Lakshmanaswamy, R. Gedunin inhibits pancreatic cancer by altering sonic hedgehog signaling pathway. Oncotarget 2016, 8, 10891-10904. [CrossRef] [PubMed]

236. Li, H.; Lui, N.; Cheng, T.; Tseng, H.-H.K.; Yue, D.; Giroux-Leprieur, E.; Do, H.T.; Sheng, Q.; Jin, J.Q.; Luh, T.W.; et al. Gli as a Novel Therapeutic Target in Malignant Pleural Mesothelioma. PLoS ONE 2013, 8, e57346. [CrossRef] [PubMed]

237. Infante, P.; Mori, M.; Alfonsi, R.; Ghirga, F.; Aiello, F.; Toscano, S.; Ingallina, C.; Siler, M.; Cucchi, D.; Po, A.; et al. Gli1/DNA interaction is a druggable target for Hedgehog-dependent tumors. EMBO J. 2015, 34, 200-217. [CrossRef] [PubMed]

238. Arai, M.A.; Uchida, K.; Sadhu, S.K.; Ahmed, F.; Ishibashi, M. Physalin H from Solanum nigrum as an Hh signaling inhibitor blocks GLI1-DNA-complex formation. Beilstein J. Org. Chem. 2014, 10, 134-140. [CrossRef] [PubMed]

239. Arai, M.A.; Fujimatsu, T.; Uchida, K.; Sadhu, S.K.; Ahmed, F.; Ishibashi, M. Hh signaling inhibitors from Vitex negundo; naturally occurring inhibitors of the GLI1-DNA complex. Mol. Biosyst. 2013, 9, 1012-1018. [CrossRef] [PubMed]

240. Yang, J.; Huang, W.; Tan, W. Solasonine, A Natural Glycoalkaloid Compound, Inhibits Gli-Mediated Transcriptional Activity. Molecules 2016, 21, 1364. [CrossRef] [PubMed]

241. Hyman, J.M.; Firestone, A.J.; Heine, V.M.; Zhao, Y.; Ocasio, C.A.; Han, K.; Sun, M.; Rack, P.G.; Sinha, S.; $\mathrm{Wu}$, J.J.; et al. Small-molecule inhibitors reveal multiple strategies for Hedgehog pathway blockade. Proc. Natl. Acad. Sci. USA 2009, 106, 14132-14137. [CrossRef] [PubMed] 
242. Jeng, K.-S.; Jeng, C.-J.; Sheen, I.-S.; Wu, S.-H.; Lu, S.-J.; Wang, C.-H.; Chang, C.-F. Glioma-Associated Oncogene Homolog Inhibitors Have the Potential of Suppressing Cancer Stem Cells of Breast Cancer. Int. J. Mol. Sci. 2018, 19, 1375. [CrossRef] [PubMed]

243. Ming, J.; Sun, B.; Li, Z.; Lin, L.; Meng, X.; Han, B.; Wang, R.; Wu, P.; Li, J.; Cai, J.; et al. Aspirin inhibits the SHH/GLI1 signaling pathway and sensitizes malignant glioma cells to temozolomide therapy. Aging (Albany NY) 2017, 9, 1233-1247. [CrossRef] [PubMed]

244. Yu, D.; Shin, H.-S.; Lee, Y.S.; Lee, D.; Kim, S.; Lee, Y.C. Genistein attenuates cancer stem cell characteristics in gastric cancer through the downregulation of Gli1. Oncol. Rep. 2014, 31, 673-678. [CrossRef] [PubMed]

245. Fan, P.; Fan, S.; Wang, H.; Mao, J.; Shi, Y.; Ibrahim, M.M.; Ma, W.; Yu, X.; Hou, Z.; Wang, B.; et al. Genistein decreases the breast cancer stem-like cell population through Hedgehog pathway. Stem Cell Res. Ther. 2013, 4, 146. [CrossRef] [PubMed]

246. Trinh, T.N.; McLaughlin, E.A.; Abdel-Hamid, M.K.; Gordon, C.P.; Bernstein, I.R.; Pye, V.; Cossar, P.; Sakoff, J.A.; McCluskey, A. Quinolone-1-(2H)-ones as hedgehog signalling pathway inhibitors. Org. Biomol. Chem. 2016, 14, 6304-6315. [CrossRef] [PubMed]

247. Liu, G.; Huang, W.; Wang, J.; Liu, X.; Yang, J.; Zhang, Y.; Geng, Y.; Tan, W.; Zhang, A. Discovery of Novel Macrocyclic Hedgehog Pathway Inhibitors Acting by Suppressing the Gli-Mediated Transcription. J. Med. Chem. 2017, 60, 8218-8245. [CrossRef] [PubMed]

248. Wolff, F.; Loipetzberger, A.; Gruber, W.; Esterbauer, H.; Aberger, F.; Frischauf, A.M. Imiquimod directly inhibits Hedgehog signalling by stimulating adenosine receptor/protein kinase A-mediated GLI phosphorylation. Oncogene 2013, 32, 5574-5581. [CrossRef] [PubMed]

249. Yamanaka, H.; Oue, T.; Uehara, S.; Fukuzawa, M. Forskolin, a Hedgehog signal inhibitor, inhibits cell proliferation and induces apoptosis in pediatric tumor cell lines. Mol. Med. Rep. 2010, 3, 133-139. [CrossRef] [PubMed]

250. Xin, Y.; Shen, X.; Cheng, L.; Hong, D.; Chen, B. Perifosine inhibits S6K1-Gli1 signaling and enhances gemcitabine-induced anti-pancreatic cancer efficiency. Cancer Chemother. Pharmacol. 2014, 73, 711-719. [CrossRef] [PubMed]

251. Nayak, A.; Siddharth, S.; Das, S.; Nayak, D.; Sethy, C.; Kundu, C.N. Nanoquinacrine caused apoptosis in oral cancer stem cells by disrupting the interaction between GLI1 and $\beta$ catenin through activation of GSK3 $\beta$. Toxicol. Appl. Pharmacol. 2017, 330, 53-64. [CrossRef] [PubMed]

252. Tang, Y.; Gholamin, S.; Schubert, S.; Willardson, M.I.; Lee, A.; Bandopadhayay, P.; Bergthold, G.; Masoud, S.; Nguyen, B.; Vue, N.; et al. Epigenetic targeting of Hedgehog pathway transcriptional output through BET bromodomain inhibition. Nat. Med. 2014, 20, 732-740. [CrossRef] [PubMed]

253. Long, J.; Li, B.; Rodriguez-Blanco, J.; Pastori, C.; Volmar, C.-H.; Wahlestedt, C.; Capobianco, A.; Bai, F.; Pei, X.-H.; Ayad, N.G.; et al. The BET Bromodomain Inhibitor I-BET151 Acts Downstream of Smoothened Protein to Abrogate the Growth of Hedgehog Protein-driven Cancers. J. Biol. Chem. 2014, 289, 35494-35502. [CrossRef] [PubMed]

254. Yang, D.; Cao, F.; Ye, X.; Zhao, H.; Liu, X.; Li, Y.; Shi, C.; Wang, H.; Zhou, J. Arsenic Trioxide Inhibits the Hedgehog Pathway Which Is Aberrantly Activated in Acute Promyelocytic Leukemia. AHA 2013, 130, 260-267. [CrossRef] [PubMed]

255. Dhanyamraju, P.K.; Holz, P.S.; Finkernagel, F.; Fendrich, V.; Lauth, M. Histone deacetylase 6 represents a novel drug target in the oncogenic Hedgehog signaling pathway. Mol. Cancer Ther. 2015, 14, 727-739. [CrossRef] [PubMed]

256. Ingallina, C.; Costa, P.M.; Ghirga, F.; Klippstein, R.; Wang, J.T.; Berardozzi, S.; Hodgins, N.; Infante, P.; Pollard, S.M.; Botta, B.; et al. Polymeric glabrescione B nanocapsules for passive targeting of Hedgehog-dependent tumor therapy in vitro. Nanomedicine (London) 2017, 12, 711-728. [CrossRef] [PubMed]

257. Chenna, V.; Hu, C.; Pramanik, D.; Aftab, B.T.; Karikari, C.; Campbell, N.R.; Hong, S.-M.; Zhao, M.; Rudek, M.A.; Khan, S.R.; et al. A Polymeric Nanoparticle Encapsulated Small Molecule Inhibitor of Hedgehog Signaling (NanoHHI) Bypasses Secondary Mutational Resistance to Smoothened Antagonists. Mol. Cancer Ther. 2012, 11, 165-173. [CrossRef] [PubMed]

258. Sabol, M.; Trnski, D.; Uzarevic, Z.; Ozretic, P.; Musani, V.; Rafaj, M.; Cindric, M.; Levanat, S. Combination of Cyclopamine and Tamoxifen Promotes Survival and Migration of MCF-7 Breast Cancer Cells-Interaction of Hedgehog-Gli and Estrogen Receptor Signaling Pathways. PLoS ONE 2014, 9, e114510. [CrossRef] [PubMed] 
259. Diao, Y.; Azatyan, A.; Rahman, M.F.-U.; Zhao, C.; Zhu, J.; Dahlman-Wright, K.; Zaphiropoulos, P.G. Blockade of the Hedgehog pathway downregulates estrogen receptor alpha signaling in breast cancer cells. Oncotarget 2016, 7, 71580-71593. [CrossRef] [PubMed]

260. Paret, C.; Russo, A.; Otto, H.; Mayer, A.; Zahnreich, S.; Wagner, W.; Samuel, D.; Scharnhorst, D.; Solomon, D.A.; Dhall, G.; et al. Personalized therapy: CNS HGNET-BCOR responsiveness to arsenic trioxide combined with radiotherapy. Oncotarget 2017, 8, 114210-114225. [CrossRef] [PubMed]

261. Ally, M.S.; Ransohoff, K.; Sarin, K.; Atwood, S.X.; Rezaee, M.; Bailey-Healy, I.; Kim, J.; Beachy, P.A.; Chang, A.L.S.; Oro, A.; et al. Effects of Combined Treatment With Arsenic Trioxide and Itraconazole in Patients With Refractory Metastatic Basal Cell Carcinoma. JAMA Dermatol. 2016, 152, 452-456. [CrossRef] [PubMed]

262. Latuske, E.-M.; Stamm, H.; Klokow, M.; Vohwinkel, G.; Muschhammer, J.; Bokemeyer, C.; Jücker, M.; Kebenko, M.; Fiedler, W.; Wellbrock, J. Combined inhibition of GLI and FLT3 signaling leads to effective anti-leukemic effects in human acute myeloid leukemia. Oncotarget 2017, 8, 29187-29201. [CrossRef] [PubMed]

263. Kurebayashi, J.; Koike, Y.; Ohta, Y.; Saitoh, W.; Yamashita, T.; Kanomata, N.; Moriya, T. Anti-cancer stem cell activity of a hedgehog inhibitor GANT61 in estrogen receptor-positive breast cancer cells. Cancer Sci. 2017, 108, 918-930. [CrossRef] [PubMed]

264. Gonnissen, A.; Isebaert, S.; McKee, C.M.; Muschel, R.J.; Haustermans, K. The Effect of Metformin and GANT61 Combinations on the Radiosensitivity of Prostate Cancer Cells. Int. J. Mol. Sci. 2017, 18, 399. [CrossRef] [PubMed]

265. Koike, Y.; Ohta, Y.; Saitoh, W.; Yamashita, T.; Kanomata, N.; Moriya, T.; Kurebayashi, J. Anti-cell growth and anti-cancer stem cell activities of the non-canonical hedgehog inhibitor GANT61 in triple-negative breast cancer cells. Breast Cancer 2017, 24, 683-693. [CrossRef] [PubMed]

266. Li, J.; Cai, J.; Zhao, S.; Yao, K.; Sun, Y.; Li, Y.; Chen, L.; Li, R.; Zhai, X.; Zhang, J.; et al. GANT61, a GLI inhibitor, sensitizes glioma cells to the temozolomide treatment. J. Exp. Clin. Cancer Res. 2016, 35, 184. [CrossRef] [PubMed]

267. Shahi, M.H.; Farheen, S.; Mariyath, M.P.M.; Castresana, J.S. Potential role of Shh-Gli1-BMI1 signaling pathway nexus in glioma chemoresistance. Tumour Biol. 2016, 37, 15107-15114. [CrossRef] [PubMed]

268. Miyazaki, Y.; Matsubara, S.; Ding, Q.; Tsukasa, K.; Yoshimitsu, M.; Kosai, K.; Takao, S. Efficient elimination of pancreatic cancer stem cells by hedgehog/GLI inhibitor GANT61 in combination with mTOR inhibition. Mol. Cancer 2016, 15, 49. [CrossRef] [PubMed]

269. Mohapatra, P.; Satapathy, S.R.; Siddharth, S.; Das, D.; Nayak, A.; Kundu, C.N. Resveratrol and curcumin synergistically induces apoptosis in cigarette smoke condensate transformed breast epithelial cells through a p21(Waf1/Cip1) mediated inhibition of Hh-Gli signaling. Int. J. Biochem. Cell Biol. 2015, 66, 75-84. [CrossRef] [PubMed]

270. Cai, X.; Yu, K.; Zhang, L.; Li, Y.; Li, Q.; Yang, Z.; Shen, T.; Duan, L.; Xiong, W.; Wang, W. Synergistic inhibition of colon carcinoma cell growth by Hedgehog-Gli1 inhibitor arsenic trioxide and phosphoinositide 3-kinase inhibitor LY294002. OncoTargets Ther. 2015, 8, 877-883. [CrossRef]

271. Pan, D.; Li, Y.; Li, Z.; Wang, Y.; Wang, P.; Liang, Y. Gli inhibitor GANT61 causes apoptosis in myeloid leukemia cells and acts in synergy with rapamycin. Leuk. Res. 2012, 36, 742-748. [CrossRef] [PubMed]

272. Wang, X.; Wei, S.; Zhao, Y.; Shi, C.; Liu, P.; Zhang, C.; Lei, Y.; Zhang, B.; Bai, B.; Huang, Y.; et al. Anti-proliferation of breast cancer cells with itraconazole: Hedgehog pathway inhibition induces apoptosis and autophagic cell death. Cancer Lett. 2017, 385, 128-136. [CrossRef] [PubMed]

273. Graab, U.; Hahn, H.; Fulda, S. Identification of a novel synthetic lethality of combined inhibition of hedgehog and PI3K signaling in rhabdomyosarcoma. Oncotarget 2015, 6, 8722-8735. [CrossRef] [PubMed]

274. Kebenko, M.; Drenckhan, A.; Gros, S.J.; Jücker, M.; Grabinski, N.; Ewald, F.; Grottke, A.; Schultze, A.; Izbicki, J.R.; Bokemeyer, C.; et al. ErbB2 signaling activates the Hedgehog pathway via PI3K-Akt in human esophageal adenocarcinoma: Identification of novel targets for concerted therapy concepts. Cell. Signal. 2015, 27, 373-381. [CrossRef] [PubMed]

275. Machado, D.; Shishido, S.M.; Queiroz, K.C.S.; Oliveira, D.N.; Faria, A.L.C.; Catharino, R.R.; Spek, C.A.; Ferreira, C.V. Irradiated Riboflavin Diminishes the Aggressiveness of Melanoma In Vitro and In Vivo. PLoS ONE 2013, 8, e54269. [CrossRef] [PubMed] 
276. Wu, F.; Rom, W.N.; Koshiji, M.; Mo, Y.; Hosomi, Y.; Tchou-Wong, K.-M. Role of GLI1 and NDRG1 in Increased Resistance to Apoptosis Induction. J. Environ. Pathol. Toxicol. Oncol. 2015, 34, 213-225. [CrossRef] [PubMed]

277. Wang, F.; Wang, W.; Li, J.; Zhang, J.; Wang, X.; Wang, M. Sulforaphane reverses gefitinib tolerance in human lung cancer cells via modulation of sonic hedgehog signaling. Oncol. Lett. 2018, 15, 109-114. [CrossRef] [PubMed]

278. Armas-López, L.; Piña-Sánchez, P.; Arrieta, O.; de Alba, E.G.; Ortiz-Quintero, B.; Santillán-Doherty, P.; Christiani, D.C.; Zúñiga, J.; Ávila-Moreno, F. Epigenomic study identifies a novel mesenchyme homeobox2-GLI1 transcription axis involved in cancer drug resistance, overall survival and therapy prognosis in lung cancer patients. Oncotarget 2017, 8, 67056-67081. [CrossRef] [PubMed]

279. Giroux Leprieur, E.; Vieira, T.; Antoine, M.; Rozensztajn, N.; Rabbe, N.; Ruppert, A.-M.; Lavole, A.; Cadranel, J.; Wislez, M. Sonic Hedgehog Pathway Activation Is Associated with Resistance to Platinum-Based Chemotherapy in Advanced Non-Small-Cell Lung Carcinoma. Clin. Lung Cancer 2016, 17, 301-308. [CrossRef] [PubMed]

280. Della Corte, C.M.; Bellevicine, C.; Vicidomini, G.; Vitagliano, D.; Malapelle, U.; Accardo, M.; Fabozzi, A.; Fiorelli, A.; Fasano, M.; Papaccio, F.; et al. SMO Gene Amplification and Activation of the Hedgehog Pathway as Novel Mechanisms of Resistance to Anti-Epidermal Growth Factor Receptor Drugs in Human Lung Cancer. Clin. Cancer Res. 2015, 21, 4686-4697. [CrossRef] [PubMed]

281. Tripathi, K.; Mani, C.; Barnett, R.; Nalluri, S.; Bachaboina, L.; Rocconi, R.P.; Athar, M.; Owen, L.B.; Palle, K. Gli1 protein regulates the S-phase checkpoint in tumor cells via Bid protein, and its inhibition sensitizes to DNA topoisomerase 1 inhibitors. J. Biol. Chem. 2014, 289, 31513-31525. [CrossRef] [PubMed]

282. Zhang, L.; Song, R.; Gu, D.; Zhang, X.; Yu, B.; Liu, B.; Xie, J. The role of GLI1 for 5-Fu resistance in colorectal cancer. Cell Biosci. 2017, 7, 17. [CrossRef] [PubMed]

283. Falkenberg, K.J.; Newbold, A.; Gould, C.M.; Luu, J.; Trapani, J.A.; Matthews, G.M.; Simpson, K.J.; Johnstone, R.W. A genome scale RNAi screen identifies GLI1 as a novel gene regulating vorinostat sensitivity. Cell Death Differ. 2016, 23, 1209-1218. [CrossRef] [PubMed]

284. Yu, B.; Gu, D.; Zhang, X.; Li, J.; Liu, B.; Xie, J. GLI1-mediated regulation of side population is responsible for drug resistance in gastric cancer. Oncotarget 2017, 8, 27412-27427. [CrossRef] [PubMed]

285. Yu, B.; Gu, D.; Zhang, X.; Liu, B.; Xie, J. The role of GLI2-ABCG2 signaling axis for 5Fu resistance in gastric cancer. J. Genet. Genom. 2017, 44, 375-383. [CrossRef] [PubMed]

286. Xu, M.; Gong, A.; Yang, H.; George, S.K.; Jiao, Z.; Huang, H.; Jiang, X.; Zhang, Y. Sonic hedgehog-glioma associated oncogene homolog 1 signaling enhances drug resistance in CD44(+)/Musashi-1(+) gastric cancer stem cells. Cancer Lett. 2015, 369, 124-133. [CrossRef] [PubMed]

287. Tang, C.-M.; Lee, T.E.; Syed, S.A.; Burgoyne, A.M.; Leonard, S.Y.; Gao, F.; Chan, J.C.; Shi, E.; Chmielecki, J.; Morosini, D.; et al. Hedgehog pathway dysregulation contributes to the pathogenesis of human gastrointestinal stromal tumors via GLI-mediated activation of KIT expression. Oncotarget 2016, 7, 78226-78241. [CrossRef] [PubMed]

288. Wadhwa, R.; Wang, X.; Baladandayuthapani, V.; Liu, B.; Shiozaki, H.; Shimodaira, Y.; Lin, Q.; Elimova, E.; Hofstetter, W.L.; Swisher, S.G.; et al. Nuclear expression of Gli-1 is predictive of pathologic complete response to chemoradiation in trimodality treated oesophageal cancer patients. Br. J. Cancer 2017, 117, 648-655. [CrossRef] [PubMed]

289. Ding, J.; Zhou, X.-T.; Zou, H.-Y.; Wu, J. Hedgehog signaling pathway affects the sensitivity of hepatoma cells to drug therapy through the ABCC1 transporter. Lab. Investig. 2017, 97, 819-832. [CrossRef] [PubMed]

290. Melamed, J.R.; Morgan, J.T.; Ioele, S.A.; Gleghorn, J.P.; Sims-Mourtada, J.; Day, E.S. Investigating the role of Hedgehog/GLI1 signaling in glioblastoma cell response to temozolomide. Oncotarget 2018, 9, 27000-27015. [CrossRef] [PubMed]

291. Wang, K.; Chen, D.; Qian, Z.; Cui, D.; Gao, L.; Lou, M. Hedgehog/Gli1 signaling pathway regulates MGMT expression and chemoresistance to temozolomide in human glioblastoma. Cancer Cell Int. 2017, $17,117$. [CrossRef] [PubMed]

292. Furukawa, J.; Miyake, H.; Fujisawa, M. GLI2 expression levels in radical nephrectomy specimens as a predictor of disease progression in patients with metastatic clear cell renal cell carcinoma following treatment with sunitinib. Mol. Clin. Oncol. 2016, 5, 186-192. [CrossRef] [PubMed] 
293. Song, X.; Yan, L.; Lu, C.; Zhang, C.; Zhu, F.; Yang, J.; Jing, H.; Zhang, Y.; Qiao, J.; Guo, H. Activation of hedgehog signaling and its association with cisplatin resistance in ovarian epithelial tumors. Oncol. Lett. 2018, 15, 5569-5576. [CrossRef] [PubMed]

294. Zhang, W.; Yu, F.; Wang, Y.; Zhang, Y.; Meng, L.; Chi, Y. Rab23 promotes the cisplatin resistance of ovarian cancer via the Shh-Gli-ABCG2 signaling pathway. Oncol. Lett. 2018, 15, 5155-5160. [CrossRef] [PubMed]

295. Whitson, R.J.; Lee, A.; Urman, N.M.; Mirza, A.; Yao, C.Y.; Brown, A.S.; Li, J.R.; Shankar, G.; Fry, M.A.; Atwood, S.X.; et al. Noncanonical hedgehog pathway activation through SRF-MKL1 promotes drug resistance in basal cell carcinomas. Nat. Med. 2018, 24, 271-281. [CrossRef] [PubMed]

296. Gan, G.N.; Eagles, J.; Keysar, S.B.; Wang, G.; Glogowska, M.J.; Altunbas, C.; Anderson, R.T.; Le, P.N.; Morton, J.J.; Frederick, B.; et al. Hedgehog signaling drives radioresistance and stroma-driven tumor repopulation in head and neck squamous cancers. Cancer Res. 2014, 74, 7024-7036. [CrossRef] [PubMed]

297. Tang, B.; Xu, A.; Xu, J.; Huang, H.; Chen, L.; Su, Y.; Zhang, L.; Li, J.; Fan, F.; Deng, J.; et al. MicroRNA-324-5p regulates stemness, pathogenesis and sensitivity to bortezomib in multiple myeloma cells by targeting hedgehog signaling. Int. J. Cancer 2018, 142, 109-120. [CrossRef] [PubMed]

298. Zhang, X.; Liu, Y.; Lu, L.; Huang, S.; Ding, Y.; Zhang, Y.; Guo, Q.; Li, Z.; Zhao, L. Oroxyloside A Overcomes Bone Marrow Microenvironment-Mediated Chronic Myelogenous Leukemia Resistance to Imatinib via Suppressing Hedgehog Pathway. Front. Pharmacol. 2017, 8, 526. [CrossRef] [PubMed]

299. Li, X.; Chen, F.; Zhu, Q.; Ding, B.; Zhong, Q.; Huang, K.; Jiang, X.; Wang, Z.; Yin, C.; Zhu, Y.; et al. Gli-1/PI3K/AKT/NF-kB pathway mediates resistance to radiation and is a target for reversion of responses in refractory acute myeloid leukemia cells. Oncotarget 2016, 7, 33004-33015. [CrossRef] [PubMed]

300. Zahreddine, H.A.; Culjkovic-Kraljacic, B.; Assouline, S.; Gendron, P.; Romeo, A.A.; Morris, S.J.; Cormack, G.; Jaquith, J.B.; Cerchietti, L.; Cocolakis, E.; et al. The sonic hedgehog factor GLI1 imparts drug resistance through inducible glucuronidation. Nature 2014, 511, 90-93. [CrossRef] [PubMed]

301. Santisteban, M. ABC transporters as molecular effectors of pancreatic oncogenic pathways: The Hedgehog-GLI model. J. Gastrointest. Cancer 2010, 41, 153-158. [CrossRef] [PubMed]

302. Amable, L.; Fain, J.; Gavin, E.; Reed, E. Gli1 contributes to cellular resistance to cisplatin through altered cellular accumulation of the drug. Oncol. Rep. 2014, 32, 469-474. [CrossRef] [PubMed] 